\title{
Sinema ve Resim Ekseninde Medyalararası Bir İnceleme: Așçı, Hırsız, Karısı ve Așığı Filmi
}

\section{An Intermedial Analysing in the Axis of Cinema and Painting: The Cook, the Thief, His Wife and Her Lover Movie}

\author{
Özge Boz ${ }^{1}$
}

\section{Öz}

Bu çalışma, Peter Greenaway'in 1989 yıında çektiği Aşçı, Hırsız, Karısı ve Aşığı filmi ile filmin hem mecazi hem de gerçek anlamda fonunu oluşturan Frans Hals'ın Aziz Giorgio Birliğinin Subayları Ziyafette resmini medyalararası bir okumayla ele almaktadır. Filmin ana mekanı olan restoranda, filmin ana karakterlerinin yer aldığı masanın hemen ardında asılı duran bu tablo, sadece biçimsel değil anlatısal olarak da film evreninin oluşmasında kilit taşı görevi görmektedir. Biçimci olan Greenaway, ışık, renk, kompozisyon, dekor, kostüm ve sahneleme gibi mizansen öğelerinde stilistik bir yaklaşım sergilediğinden dolayı film, mizansen analiz yöntemiyle incelenmiştir. Yönetmenin, filminde inşa ettiği çok katmanlı anlam yapısında derinlere inebilmek, filmi çözümlemek ve gerekli olan kültürel alt yapıyı sağlamak için Aziz Giorgio Birliğinin Subayları Ziyafette tablosuyla beraber eserin üretildiği dönem de çalışmanın kapsamına dahil edilmiştir. Tablonun ışık, renk ve kompozisyon gibi estetik unsurlarının yansıması filmin mizanseninde görülürken, eserin üretildiği 17. yüzyıl Hollanda'sının sosyal, ekonomik, politik ve sanatsal yaşantısının filmin öyküsünün oluşturulmasında başat bir rol oynadığı anlaşılmaktadır.

Anahtar Kelimeler: Peter Greenaway, Aşçı, Hırsız, Karısı ve Aşı̆̆ı, Mizansen Analiz, Sinema ve Resim, Medyalararasılık.

\section{Abstract}

This study approaches with an intermedial analysing of the film of The Cook, the Thief, His Wife and Her Lover filmed by Peter Greenaway in 1989 and the painting of The Banquet of the Officers of the St George Militia Company in 1616 painted by Frans Hals which creates the background of the movie in both metaphoric and literal meanings. The painting hanging on the wall right behind of the table where all the main characters play a part in the main venue of the film, restaurant; acts as a keystone to create the universe of the film as both stylistic and narrative. Greenaway who is formalist, takes a stylistic method in mise-en-scene elements as are light, colour, composition, decoration, costume and screening. Therefore, this film analysed with mise-en-scene analysing method. In order to go deeper in the multi-layered meaning structure that the director has built in his film and to provide the requisite cultural background in the purpose of analysing the film, the period in which the work of art was produced is also included in the scope of the studying along with the painting of The Banquet of the Officers of the St George Militia Company in 1616. While the reflection of the aesthetic components of the painting such as light, colour and composition are seen in the mise-en-scene of the film, it is understood that the results of the social, economic, political and artistic life of the 17th century of Netherlands, where the work of art was produced, played an essential role in the creation of the story of the film.

Key words: Peter Greenaway, The Cook, the Thief, His Wife and Her Lover, Mise-en-scene analysing, Cinema and Painting, Intermediality.

Araștırma Makalesi (Research Article)

Gönderim Tarihi (Received): 17.08.2020

Kabul Tarihi (Accepted): 19.03.2021
Atıf (cite as): Boz, Özge. (2021). Sinema ve Resim Ekseninde Medyalararası Bir İnceleme: Așçı, Hırsız, Karısı ve Așığı Filmi. Akdeniz Üniversitesi Iletișim Fakültesi Dergisi, 35, s. 262-283, DOI: 10.31123/akil.781782

1 Arş. Gör., Nişantaşı Üniversitesi, Radyo, Sinema ve Televizyon Bölümü, ozge.boz@nisantasi.edu.tr, Orcid (ID): 0000-0002-2168-9308 


\section{Giriș}

Birikimini on binlerce yıldan alan resim, tiyatro ve edebiyat gibi köklü sanat dallarını bünyesine dahil eden sinema, henüz yaklaşık 120 yıllık geçmişine rağmen diğer sanatlar arasında etkin bir şekilde yerini almıştır. Sinemaya dair teknik kitaplar incelendiğinde pek çoğunun mizansene dair unsurları resimden başlayarak anlattığı ve örnekler için tablolardan yararlandığı görülür. Mizansen'in öğelerinden olan aydınlatmada (Caravaggio ve Rembrandt aydınlatması vb.), renk kullanımında, kompozisyonu ve hareketleri oluşturmada (altın oranlar vb.), çerçevelemede ve daha birçok öğede yüzyıllar öncesinde keşfedilen ve resim yaparken kullanılan çözümlemelere başvurulur. Sinema, zaman ve uzam bağlamında resme oranla çok daha kapsayıcı bir yapıya sahip olmasına rağmen resmin, iki boyutlu düzlemde hareket ve duygusal etki yaratma, kısıtlı bir alan olan çerçeve içerisinde defalarca kez okuma yapma ve anlam yaratma özelliğinden dolayı resim sanatından etkilenir. Bu farkın oluşmasındaki etmen, iki sanatın da kendilerine özgü devinim yaratma biçiminde saklıdır. Karakaya, resim ve sinemayı karşılaştırdığı makalesinde devingenlik üzerinde durur. Sinema, başta kurgu olmak üzere kamera hareketleriyle, çekim ölçekleri ve açıları gibi sinemasal anlatıma dair öğelerle bu devinimi sağlarken resmin devinim sağlama yöntemindeyse kompozisyon yatar. Sinemanın hareket konusunda teknik yapısından kaynaklanan bu üstünlüğüne rağmen resmin etkileyici yanı ise soyutlamadır (Karakaya, 2015, s. 140). Temelde arka arkaya gelen birçok resim veya fotoğraf karesinden meydana gelen sinema, anlatı gücünü tekniğinden ve diğer sanatlara oranla gerçeğe en yakın olmasından alır. Buna karşın resmin gücüyse soyutlama yoluyla çağrışım yapma, yeni anlamlar doğurma özgürlüğünde yatar. Bu sayede seyirciye geniş bir okuma ve duygulanım alanı açar.

Resmin sembolik yapısı ve anlatıya olan mesafesi, sinemanın potansiyelini açığa çıkarmak isteyen bazı sinemacıların ilgisini çekmiş ve resim sanatının sinemaya taşınmasına vesile olmuştur. Bu yönetmenler, sahnelerini oluşturan planları tıpkı bir ressamın tablo yaratması gibi titizlikle tasarlayarak birinci sanatla yedinci sanatı buluşturmuşlardır. Bonitzer'in (2011, s. 130) dediği gibi "Sinemacıyı ressama, sinemayı resme yaklaştıran, planların yapılışıdır." Bu nedenle biçimsel yapısını resme yaslayan bu tip filmlerde, resme ait olan devinim öğelerinden rengin, ışığın ve kompozisyonun ön planda olduğu görülür. Bonitzer (2011, s. 133-135), tabloların yoruma açık yapısının sinemadaki tablo-planlarla ikiye katlandığını ifade ederek tablo-planların sinema seyircisini pasif konumdan çıkardığına dikkat çeker: "Tablo-plan her zaman, izleyicinin kültürel bir ön hazırlığını gerektirmekle kalmaz, okumaya, şifre çözmeye bir çağrı da içerir."

Bonitzer'in dile getirdiği bu çağrıya filmlerinde yer veren yönetmenlerinden biri de Peter Greenaway'dir. Greenaway'in eserlerinde sadece film değil, filmde yer alan tablolar ve tablo-planlar da seyircinin bilgi ve kültür birikimi oranında çözümlenmeyi bekler. Kodlar kırıldıkça birbirleri arasındaki bağlar açığa çıkarak filmin anlam katmanları arasında seyircinin dolaşmasını sağlayan medyalararası merdivenler oluşur. Medyalararasılık, edebiyat, film, resim, fotoğraflar ve diğer medyaların "farklı ifade biçimlerinin ve algılayıcısına ulaştırdığı ileti içeriklerinin birbirlerine giderek daha çok yaklaşması, kimi durumlarda ise açıkça iç içe geçmesi durumuna" verilen addır (Gökşenli, 2009, s. 28). Gökşenli (2009, s. 28), Irina Rajevsky'den aktararak medyalararasılıkla ilgili şöyle yazar:

\footnotetext{
"Yazınsal bir metnin, bir filmin ya da tablonun yabancı bir medyanın belli bir ürününe ya da o yabancı medyanın semiyotik sistemine, belli alt sistemlerine ya da söylem biçimlerine gönderme yapmasına, bunları taklit etmesine işaret etmektedir."
} 
Bu nedenle çalışmada öncelikle Peter Greenaway ve resimle ilişkisi, sonrasındaysa Aşçı, Hırsız, Karısı ve Aşı̆̆ı filminin tarihi fonu olan 17. yüzyıl Hollanda'sı özetlenecektir. Filmin biçimsel anlamda yaslandığı Barok dönem ile Rembrandt etkisinden ve anlatıyı çözümlemede yardımcı unsurlar içermesi bakımından resim türleri olan janr ve natürmorttan bahsedilecektir. Filmin hem mecazi hem de gerçek anlamda arka planını oluşturan Aziz Giorgio Birliğinin Subayları Ziyafette tablosu incelendikten sonra tüm bu bilgiler ışığında Aşçı, Hırsız, Karısı ve Aşığı filmi, resme dair öğeler üzerinde durularak nitel araştırma yöntemlerinden, biçem analiz türlerinden biri olan mizansen analiz yöntemiyle çözümlenecektir. Kabadayı (2013, s. 115), mizansen eleştirisinin kamera hareketleri, aydınlatma tercihleri ve planlar arasındaki ilişki gibi sekansların teknik incelemesine dayandığını belirtir. Bu nedenle çalışmanın son kısmında filmin içeriği, biçimsel özellikleri, mizansende ön plana çıkan renk ve aydınlatma stili, mekan ilişkisi ve bu öğelerin anlatıdaki yansıması olan karakter temsilleri ele alınacaktır.

\section{Peter Greenaway ve Resim}

5 Nisan 1942'de Galler'de doğan Peter Greenaway, on iki yaşında ressam olmaya karar vermiş ve üniversiteyi Londra'daki Walthamstow Sanat Koleji'nde resim eğitimi alarak tamamlamıştır. Yirmi iki yaşındayken $16 \mathrm{~mm}$ Bolex model kamera alarak sinema üzerine yoğunlaşmaya karar veren Greenaway, daha sonra İngiltere hükümetinin iletişim ve pazarlama departmanında film editörü ve yönetmen olarak görev almıştır. 1961 yılında ilk kısa filmini çeken yönetmen, bu tarihten 2017 yılına dek 7 televizyon yapımı, 16 belgesel, 27 kısa film, 7 opera ve tiyatro eserine imza atmış, 39 sergi açmış, 20 kurmaca uzun metraj film çekmiş ve devasa multimedya projesi olan Tulse Luper'in Çantaları'nı hayata geçirmiştir (Saskia Boddeke \& Peter Greenaway Projects; The European Graduate School; Altuntaş).

Disiplinlerarası bir tavır sergileyen ressam, yazar, şair, video artist, sanat eleştirmeni, küratör, VJ ve yönetmen Greenaway, ancak yetenekli bir sanat aşığının bünyesinde birleşebilecek bu sıfatları filmlerine de yansıtmıştır. Bu sayede imgesel üslubunu perçinlemiş ve anlatılarına çok katmanlı zeminler oluşturmuştur. Balkan Naci İslimyeli (2014), yönetmenin bu tavrını şöyle açıklar:

\footnotetext{
"Onun bilinçle yarattığı sersemletici toplam sanki okunmak için değil tarihsel yoğunluk ve kargaşanın hissedilebilmesi için tasarlanmıştır. Greenaway sinemasının en çok eleştirilen yanı olan "imgesel oburluk" birbiri üstüne biriken ve diğerini doğrulayıp yalanlayan çelişik binlerce imgesel katmanın histerik kargaşasından oluşur. (...) Onun sanatında belirgin öğeler; çok katılık, gizil alanlar, sonsuz karşıtlıklar yanında dün ve bugün, cennetle cehennem, iyilikle kötülük, erkekle dişi arasındaki dirimsel çatışmadır. Bu çok katılık sanatındaki post modern yaklaşımın göstergesi olarak okunmalıdır."
}

Aldığı eğitimlerden, mesleki ve özel yaşantısına kadar sanat ve sanat tarihiyle yoğrulan yönetmenin, filmlerinde konu aldığı karakterler çoğunlukla ressamlar, müzisyenler, yönetmenler ve mimarlar gibi sanatçılardır. Kimi zaman onların hayatlarını, yaşamlarından bir kesiti konu edinip doğrudan işlerken kimi zamansa tablo-planlar veya teknik eğilimlerini taklit ederek bu sanatçılara filmlerinde yer verir. Yönetmen, eserlerini oluştururken renk kullanımında, kostüm seçimlerinde ve şiddet, çıplaklık, ölüm gibi konuları işleyiş biçiminde aşırılıklar peşinde koşar. Onun barok üsluba yatkınlığı, bu aşırılığı ve tiyatralliği açıklar. Greenaway'in abartılı ve uç noktalarda gezen tavrı, ele aldığı konuyu anlatma biçimine de yansır. Bu nedenle filmleri, içerdiği işkence veya ölüm sahnelerinden dolayı bazı seyirciler tarafından tahammül edilemez olarak nitelendirilir. Klasik sinema seyircisini zorlayan anlatı yapısı, yönetmenin popüler sinemaya karşı sergilediği bilinçli bir tutumdur. Kendisini ana akım sinemaya ait bulmayan Greenaway, sinemada gerçekliğin peşinde koşmak yerine "yapaylığının farkında 
olan" eserlerle ilgilendiğini söyleyerek ekler; "önemli olan neyin olduğu değil, nasıl olduğudur" (Gras ve Gras, 2014, s. 73). Sinemada fikre ve özgün dile önem veren İngiliz yönetmen, kullandığı yoğun metaforlar, semboller ve deneysel girişimlerle ana akım sinemayı sarsmaya çalışır. Hikaye anlatmanın sinemanın işi olmadığını her fırsatta dile getirirken bir röportajında şöyle der:

"Sinema bence çok sıkıcı. Her şeyi, beş dakika sonra ne olacağını biliyoruz. George Clooney'in iyi bir karakter olacağını mesela. İyiler kazanacak, kötüler kaybedecek. Artık 100 yıl sonra yeni bir şeyle karşılaşmak zor. Hikaye anlatımının zamanı geçti." (Kural, 2014).

Peter Greenaway'in resimle kurduğu yakın ilişkiye bakıldığında, yirmi yılı aşkın bir süredir Amsterdam'da yaşadığı, sanatçı kimliğinin oluşmasında Hollanda'nın ve Hollandalı ressamların etkisinin olduğu fark edilir. Şensöz ve Tuncer'in (2020) yaptığı röportajda yönetmen, resim eğitimi gördüğü yıllarda Amsterdam'daki müzelerde yer alan eserlerden etkilendiğini ve sonraki yıllarda Hollandalı ressamlara öykündüğü peyzajlar yapmaya başladığını söyler. Resimlerini çoğu zaman filmlerinde tekrar canlandıran Greenaway, bu nedenle özellikle peyzaj resimlerini 16/9 oranında resmettiğini, bu sayede resimlerini kırpmadan sinemaya aktarabildiğini belirtir (Saskia Boddeke \& Peter Greenaway Projects). Ressam olarak başladığı kariyerine beyazperdede devam etmenin nasıl hissettirdiği sorusuna verdiği yanıtsa "Resimlerde maalesef ses bandı yok. Bense ses bandı olan tablolar yapmayı arzuluyordum. Bence bu bir tür sinema tanımı olabilir." şeklindedir (Şensöz ve Tuncer, 2020). Sinemayı konvansiyonel formunun dışında gerçek güç ve karakterinin ortaya çıkarılması gereken bir sanat dalı olarak görür ve filmlerini, diğer sanatlardan özellikle de resimden beslenen plastik bir eser olarak inşa eder. Greenaway'in filmlerine tezahür eden resimsel estetiği İslimyeli (2014) şöyle analiz eder:

\begin{abstract}
"Aydınlık ve karanlığın karşıtığında bütünleșen ve ayrıșan insanın değişmez yazgısı. Renkleriyse kırmızı ve siyahtır. Bu görüntü saplantısının resim tarihindeki kahramanları Caravaggio, Rembrandt, George de La Tour, Bosh, Bruegel, Vermeer ve diğer ışık ustalarıdır. Greenaway'in dünyasının bir alegoriler, semboller ve metaforlar dünyası olduğunu düşünürsek, aydınlık ve karanlığın simgesel olarak yaşamla ölüm, görünenle gizlenen, iyilikle kötülük ve insanoğlunun tüm karanlıklarının simgeleri olduğunu söyleyebiliriz. Kırmızı ve siyah ise onun sinemasında ateşle külün, tutku ve kayıpların, seks ve ölümün metaforu olarak film sahnesine girip çıkarlar."
\end{abstract}

\title{
2. 17. Yüzyılda Hollanda: Zenginlik, Burjuvazi ve Sanat
}

Greenaway, "Sinema, resimler hakkında değil, hikâyeler hakkındadır." der (Vardan, 2009). Bu nedenle Aşçı, Hırsız, Karısı ve Aşığı filminin fonuna koyduğu "Aziz Giorgio Birliğinin Subayları Ziyafette" tablosundan çok, bu tablonun hikayesi yer alır filmde. Filmin büyük bir kısmında görünen bu tablonun alt metniyse iki farklı yoldan örülmüştür: Bunlardan biri resmin sembolik anlamlarında diğeri ise resmin ait olduğu dönemde gizlidir. Hollanda sanatına öykünen Greenaway'in sinemasını anlamaya çalışırken keşfedilen doneler, ilk bakışta birbiriyle ilintisiz yapboz parçalarını anımsatırken dikkatle bakıldığında aslında tüm parçaların 17. yüzyıl Hollanda'sına ait olduğu fark edilir. Panofsky'nin belirttiği gibi bir resim, bir imge içinde bulunduğu kültürle doğrudan ilişkilidir. Resmi okumak için resmin ait olduğu dönemin üslubuna ve üslubu etkisi altına alan dönemin diğer sosyal, ekonomik ve politik olaylarına, kısaca kültürel kodlarına aşina olmak gerekmektedir. Ele alınan eser ancak bu bütünlük içerisinde yorumlanabilir ve anlaşılabilir (aktaran Çeler, 2012, s. 69). Filmin görsel inşasından anlatı unsurlarına dek pek çok farklı biçimde karşılaşılan 17. yüzyıldaki Hollanda etkisini anlayabilmek için dönemin ekonomik, dini, politik, sosyal ve sanatsal yapısına bakmak filmi çözümleme noktasında ihtiyaç duyulan kültürel zemini oluşturacaktır. 


\subsection{Hollanda}

17. yüzyılda Hollanda hem ticarette hem de sanat alanında "Altın Çağ" olarak adlandırılan bir dönemi yaşamaktadır. MaltaşveYücel'inçalışmalarındanbudönemebakılacakolursa,Avrupa'daProtestanlığın yaygınlaşması ve Kuzey Felemenk'in yani bugünkü Hollanda'nın çoğunluğunun Protestanlığa geçmesi, ekonomik, politik ve sosyolojik olarak birçok değişimi tetiklemiştir. Karaalioğlu'nun yazdığı gibi Protestanlıktan türeyen Kalvenizm ile Tanrı inancı, iş kutsalığıyla içselleştirilmiştir. Tanrı'ya hizmet etmek isteyen dindarlar bunu ancak çalışarak gerçekleştirebileceklerine inanıyorlardı. Aziz Paulus'un “Çalışmayan, yememelidir.” sözü, döneme hakim olan üretim-tüketim ilişkisini ve kapitalizmin hakimiyetini özetleyen önemli bir ifadedir (Karaalioğlu, 2018, s. 911). Bu doğrultuda yükselen inanç sistemiyle beraber ortaya çıkan çalış-kazan-tüket döngüsü Hollanda'da günlük yaşama yerleşmiş ve hızla zenginleşen geniş bir kitle yaratmıştır. Aynı zamanda Hollanda, Avrupa'da önemli ticaret yolları üzerinde tekel oluşturarak deniz taşımacılığında ve ticarette dünya çapında bir üstünlük yakalamış, yaşanan zenginleşme sonucunda orta sınıf burjuvazisi belirmiştir. Varlıklı tüccarlar ve bankerler kent yönetiminde söz sahibi olarak idari ve toplumsal alanda etkisi zayıflayan kilisenin yerine geçmişlerdir. Ekonomik güçleri ve yönetimdeki rolleriyle zamanla nüfuz ve statü kazanmışlardır.

Deniz ticaretiyle güçlenen Protestan Hollanda'da oluşan refah ortamının ve kurulan yeni düzenin etkisiyle eşine rastlanmayan bir sanat pazarı oluşmuştur. Protestanların, kiliselerdeki dini resim ve heykelleri Katolik putperestliği şeklinde adlandırması ve kilise içindeki eserlere karşı çıkmasıyla sanat, kilisenin dışına çıkmıştır. Böylece burjuvalar, sanat koruyuculuğu görevini kilise ve saraydan devralmışlardır. Zengin tüccarlar, soyluları örnek alıp evlerini tablolarla süslemeye başlamış ancak kültürel altyapılarının yetersizliği nedeniyle alımlaması görece kolay olan günlük yaşamı konu edinen resimlere yönelmişlerdir. Bu nedenle Hollanda'nın bu döneminde janr resimleri ve natürmortlar ön plana çıkmış, ressamlar çoğunlukla aynı konular üzerinde çalıştıkları için belirli türlerde ustalaşmaya başlamışlardır. Bunlardan biri de portre ressamlığıdır. Burjuva insanı, soylulara özenerek kendi resimlerini yaptırmaya başlamış hatta gruplar halinde resmedilmelerini istemişlerdir. Bu talepler doğrultusunda birden fazla kişinin genelde bir masa etrafında resmedildiği grup portreciliği ortaya çıkmıştır. Hollanda'nın natürmort ve grup portreciliği gibi farklı konulardaki resimlere öncülük ettiği bu altın çağda, yaklaşık yetmiş bin resim üretilmiş, Frans Hals, Rembrandt ve Vermeer gibi sanat tarihine yön veren usta ressamlar yetişmiştir. (Maltaş, 2005 s. IV-3; Yücel, 2007 s. 25).

\subsection{Barok Dönem ve Rembrandt}

Rönesans'ı izleyen Barok üslup, klasizme tepki olarak 17. yüzyıl başlarında Avrupa'da doğmuştur. Bu döneme ait eserlerde akıl ve uyumun aksine coşku ve ilkesizlik vardır. Simetrik kompozisyonlar yerine diyagonal bir üslup tercih edilmiştir. Kontrast kullanılan renklerse birbiri içerisinde eriyerek kaynaşmaktadır.

"Ressamlar resmin içerisindeki neden ve sonuç ilişkisinden daha çok, bir anın resmedilişi üzerinde yoğunlaşmışlardır. Açık kompozisyonu, renk ve ışık-gölge kullanımı ile güçlendirmişlerdir. Eskiden daha az önem verilen bu biçimsel özelikler, barok sanatı ile beraber anlatının en büyük faktörlerinden olmuşlardır." (Kilinç ve Köksal, 2019, s. 22).

Germaner'in belirttiği gibi Barok dönemde gösteri tutkusu ortaya çıkmıştır. Tiyatro oyunları, bayramlar, dini ve resmi törenler gibi pek çok alanda bu şaşaa kendisini hissettirmiştir. Abartıyı seven Barok 
üslup, gerçekten çok gerçek dışına meyillidir (aktaran Yücel, 2007, s. 23).

Barok dönemin ünlü ressamlardan biri de Rembrandt’tır. Özellikle ışık-gölge kullanımında pek çok ressama referans olan Rembrandt'ın bu virtüözitesi sinemada da kullanılmış, yer aldığı planlara resimsel bir aura kazandırmıştır. Kılıç'ın bahsettiği üzere 16. yüzyılda çizgisel olan batı resmi, 17. yüzyılla beraber gölgesel olmaya başlamıştır. Nasıl ki Dürer için çizgisel resmin ustası denilebilecekse Rembrandt için de gölgesel üslubun ustası denilebilir. Üç ana biçime ayrılan Chiaroscuro aydınlatmadan biri olan Rembrandt aydınlatması, çerçeveye üçüncü boyut etkisi katar. Noktasal bir kaynaktan alınan ışıkla, ele alınan konunun-nesnenin belirli bir kısmını aydınlatıp diğer kısımlarının karanlıkta bırakılmasıyla gerçekleştirilen bu aydınlatma seçici bir aydınlatma sağlar. Temel özelliğiyse zayıf bir aydınlatma ve ışıklı alanlar ile gölgeli alanlar arasındaki yumuşak geçiştir (Kılıç, 2013, s. 15-19).

İngiliz yönetmenin kimi zaman "tahammülü zor" olarak nitelendirilen anlatı biçiminde de Rembrandt'ın etkisi görülür. Greenaway, ele aldığı konularda ve karakterlerde geleneksel "güzel” anlayışının dışına çıkar. Ona göre güzel olan gerçek ve doğal olandır. Rembrandt’ın "güzel” sanatlardaki güzeli alaşağı ettiği tavrını Gombrich (2014, s. 427) şöyle açıklar:

"İtalyan sanatının güzel figürlerine alışmış bir kimse, güzelliğe hiç aldırış etmeyen, üstelik çirkinlikten de hiç çekinmeyen Rembrandt'ın resimlerini ilk kez gördüğünde oldukça rahatsız olabilir. (...) O da Caravaggio gibi, gerçeği ve içtenliği, güzellik ve uyumdan üstün tutuyordu."

\subsection{Janr ve Natürmort}

Gombrich, “(...) nasıl söz olmadan da güzel bir müzik olabilirse, aynı biçimde, önemli bir konu olmadan da güzel bir resim yapılabilir." der. 17. yüzyılda belirli türlerde uzman olan ressamlara göre konu, bir resim için ikinci dereceden önem teşkil ediyordu (Gombrich, 2014, s. 430). Mimetik tavrın hakim olduğu dönemin Hollanda'sında bu nedenle janr ve natürmort eserler ön plana çıkmıştır.

Gündelik yaşam veya tür resmi olarak da adlandırılan janr resimleri hem kiliselerde yer alan dini konulu resimlerin konusunu değiştirmiş hem de kilisedeki mesafeli yapıyı bozarak resim sanatını halka, gündelik yaşama indirgemiştir. Böylece yaşamın içinden, Hollanda kültür ve yaşantısını anlatan organik ve ulaşılabilir resimler yapılmaya başlanmıştır. Bu resimlerde, mutfağında yemek yapan bir kadından, sokakta eğlenen çocuklara veya büyük bir masa etrafında ziyafet veren işçi gruplarına dek pek çok farklı statüde insan, farklı mekan ve olaylar resmedilmiştir. Berger'e (2012, s. 103) göre bu resimler, soylu olmayan düşük yaşamı gösterdiği için kabaydı. Resimlerin yapılma amacı,

“(...) erdemliliğin toplumsal ve parasal ödüllerle değerlendirildiğini kanıtlamaktı. Böylece -çok da pahalı olmayanbu resimleri satın alabilenler kendi erdemliliklerini doğrulamış oluyorlardı. Bu tür resimler yeni ortaya çıkan kentsoylular sınıfınca çok tutuluyordu."

17. yüzyıl Hollanda'sında en yetkin örneklerini veren bir diğer resim türü ise natürmorttu. Pek çok çeşidi olan natürmortta çiçekler, masa üzerine yerleştiren sebze-meyveler, kitap ve mum gibi objeler, kuru kafaların olduğu vanitaslar ve av hayvanları resimleri oluşturan öğelerdendir. Maltaş (2005, s. 31), çalışmasında natürmortlardaki nesnelerin birincil işlevlerinin yanında dönemin kültürünü ve düşünce yapısını yansıtmada rol aldığından bahseder. Örneğin natürmortta yer alan porselen tabaklar, gümüş kaplamalı çatal-bıçaklar veya büyük et parçaları zenginliği ve soyluluğu ifade ederken tahtadan oyma kaşık ve kaseler, kolaylıkla ulaşılabilen sebzeler sıradanlığı imler. 
Tablolarda resmedilen nesneler reel olarak alınmasa dahi satın alınan resimle beraber evin içine girer. Berger (2012, s. 83), "Böylece bir resmi satın aldığınızda o resimde gösterilen nesnelerin görünüşünü de satın almış olursunuz." der. Gerçekte sahip olunan gümüş çatal zamanla kararır ve et parçası tükenirken, tabloda "dondurulan" zenginlik daimi bir imge olarak duvarda yerini alır. Leppert (2017, s. 70), anlatıdan yoksun olan natürmortların insana değil "mal"a dair olduğunu, bu natürmortları alan kişilerin sahiplik üzerinden kendilerini tanımladıklarını belirtir. Dahası burjuvaya ait olmayan kişi, böyle bir tablo satın alarak üst sınıfa ait olma arzusunu bastırır ve "mış" gibi yapar.

Toplumsal sınıfa, soyluluğa dair önemli mesajlar taşıyan natürmort çeşitlerinden biri de avcılık natürmortlarıdır. Bu resimlerde yer alan tavşan, tilki, geyik, deniz canlıları ve kuş çeşitleri hem resmin yapıldığı doğal hayata, canlı çeşitliliğine dair belge niteliği hem de resmedilen hayvanların türüne göre sosyoekonomik mesajlar taşır. Leppert, öldürülen hayvanların karın doyurma amacıyla değil de salt haz temelli tüketimi vurguladığına dikkat çeker. Bu keyfi tüketime ise herkesin erişme imkanı yoktu. Avlanmak, soylulara ve orman sahiplerinden izin alabilen az sayıda kişiye tanınan ayrıcalıklı bir eylemdi. Bu nedenle böyle bir natürmorta sahip olmak, toplumsal konumu somutlaştıran bir araç niteliği taşıyordu. Örneğin kuğu avı, izin, tarih ve sayı sınırlandırmasından dolayı oldukça sıkı kurallara bağlıydı. Bu nedenle seçkin kişilerce nadiren avlanabilen kuğuların yer aldığı natürmortlar birer prestij göstergesiydi (Leppert, 2017, s. 112-116).

\section{Frans Hals ve Aziz Giorgio Birliğinin Subayları Ziyafette Tablosu}

Hollanda'nın ilk önemli ressamı olan Frans Hals ve ailesi, Protestan olmalarından dolayı güney Felemenk’ten ayrılarak zengin bir şehir olan Haarlem'e taşınmışlardır. Burada tüccarlar ve belediye meclis üyeleri kendi portre resimlerini sipariş vermişlerdir. Varlıklı ailelerden seçilen komutanların görevlerinin sonuna geldiklerinde şereflerine ziyafet verilmesi gelenek halini almıştır. Zamanla bu ziyafetlerin anısına, subaylar ve yemek masasının yer aldığı büyük boy grup resimleri yaptırılmaya başlanmıştır (Gombrich, 2014, s. 413-414). Marien ve Fleming'e göre bu milisler, barış döneminde de varlıklarını sürdürmüş, sembollerini ve hiyerarşik yapılarını koruyarak toplumda statü kazanmışlardır. Rembrandt ve özellikle de Hals, milislerin ziyafetlerini, toplantılarını ve görev başındaki hallerini janr resmi olarak, grup tablosu şeklinde başarıyla resmetmişlerdir (aktaran Çeler, 2012, s. 76).

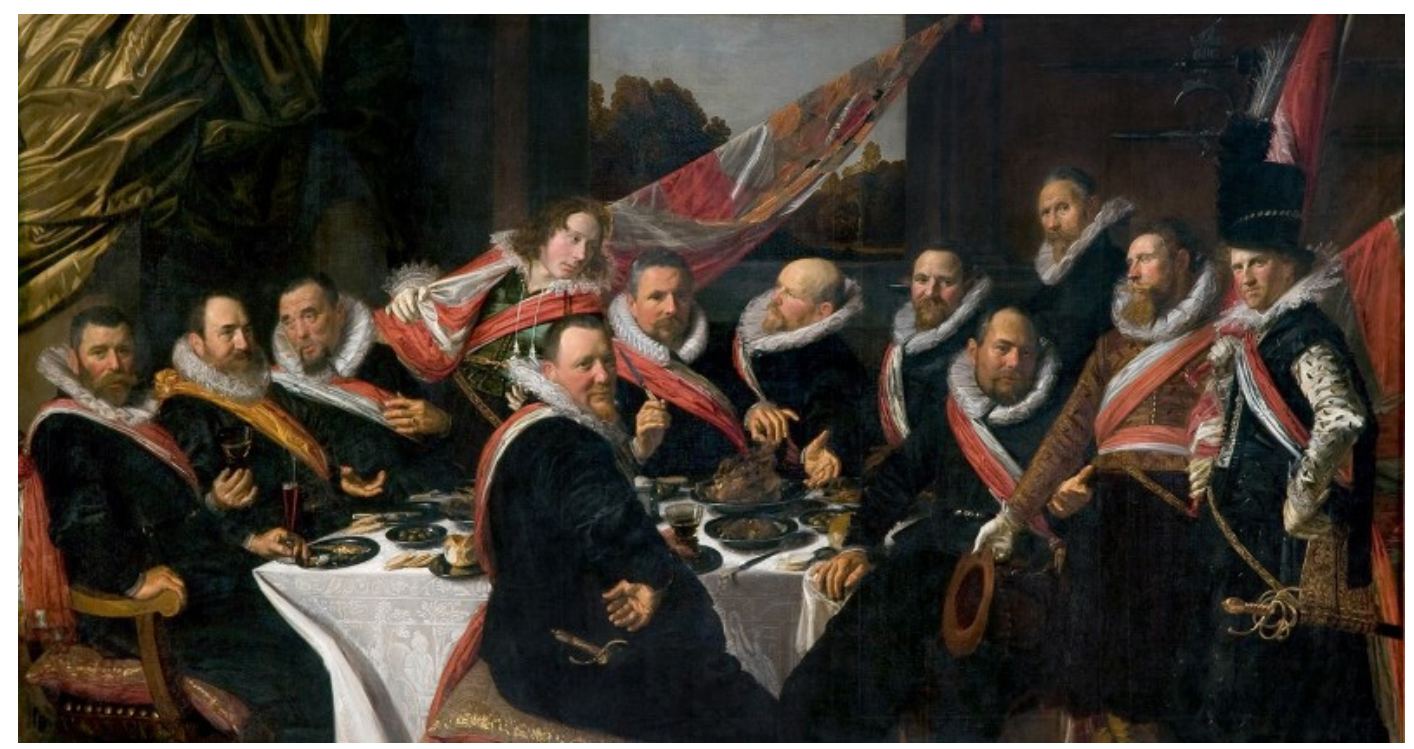

Görsel 1: Aziz Giorgio Birliğinin Subayları Ziyafette Tablosu 
Resmettiği portrelerde kişilerin ifadelerini ve mizaçlarını tuvale yansıtmadaki başarısı, Frans Hals'ı portre ressamlığında ve janr türünde benzersiz bir noktaya getirmiştir. Kişilerin o anki canlılığını, hareketini ve karakterini ortaya koymayı başarmıştır. Onu diğer ressamlardan ayıran diğer bir özelliği ise müzesinde yazdığı gibi sıradan hatta alt sınıflardan insanların da resimlerini yapmış olmasıdır. Soyluluğun, burjuvanın ve güzelin tahtını sarsan bu yaklaşımıyla, köylülerden gülen balıkçılara, sarhoşlardan sigara içen çocuklara dek çeşitli insanları resmetmiştir (Frans Hals Museum). Ressamın bahsedilen özelliklerinin görüldüğü eserlerden biri Aziz Giorgio Birliğinin Subayları Ziyafette ${ }^{2}$ tablosudur. Tablo, hem dönemin milislerinin hiyerarşik ve sosyoekonomik yapısını gösterme hem de Hals'ı diğer ressamlardan ayıran ustalığını inceleme imkanı sunması bakımından önemlidir. Frans Hals Müzesi'nde tabloya dair yapılan bilgilendirmede, resmedilen askerlerin 1612-1615 yılları arasında hizmet ettikleri yazar. Oturma düzeninin rütbelere göre hiyerarşik bir biçimde ayarlandığı eserde, masanın sol başında aralarında albayın da olduğu üst düzey askerler görülür. Masanın sonunda üç teğmen, etraflarındaysa üç yedek subay ve kurumun hizmetlisi (ayakta) yer almaktadır (Frans Hals Museum). Rütbesi düşük askerler perspektif olarak geride, ayakta durur vaziyette ve daha küçük bir alanda resmedilmişlerdir. Hals'ın yeteneği, bu on iki askerin de yüzüne tek tek bakıldığında ortaya çıkar. Her biri kendisine özgü biçimde detaylıca resmedilmiştir. Akdeniz Ay'ın bahsettiği gibi bu görkemli portrelerde yer almak isteyen askerler bir miktar para ödemek zorundaydı. Ödenen miktar ve rütbe, kimin nerede oturacağını belirliyordu. Örneğin masadaki tek turuncu kuşaklı asker olan albay hem rütbesinin hem de parasının etkisiyle masanın başında otururken ve elinde kadehle resmedilmiştir. Albayın sağında yer alan yüksek rütbeli askerin elindeyse flüt şampanya kadehi bulunmaktadır. Bu, albayla dostluklarının şerefine kaldırılmış özel bir kadehtir (Akdeniz Ay, 2017, s. 81). Yücel (2007, s. 59) ise dini bir okuma yaparak masada bulunan on iki askeri, Hz. İsa'nın on iki havarisine benzetir. Masada yer alan şarap, ekmek ve et, Hz. İsa'nın son akşam yemeğini anımsatır.

\section{Așçı, Hırsız, Karısı ve Așı̆ı}

Peter Greenaway, Aşçı, Hırsız, Karısı ve Aşığı (The Cook, the Thief, His Wife and Her Lover) filmini Şelaleler (The Falls, 1980), Ressamın Sözleşmesi (The Draughtsman's Contract, 1982), Hayvanat Bahçesi (A Zed and Two Noughts, 1985), Mimarın Karnı (The Belly of an Architect, 1987) ve Sayılarda Boğulma (Drowning by Numbers, 1988) filmlerinden sonra 1989 yılında çekmiştir. Yönetmenin en büyük ticari başarısı olarak adlandırılan ve uluslararası arenada tanınırlığını sağlayan film, IMDb verilerine göre yönetmenin en yüksek puan alan filmi olmuştur. Geleneksel sinemanın uzağında olan film, gösterime girdiği yıllarda sadece 7 ödülün sahibi olmasına karşın zamanla kült mertebesine yükselmiştir (IMDb). 120 dakika süren yapım, suç ve dram türündedir. Filme ismini veren dört karakteri, aşçı rolünde Richard Bohringer (Richard), restoran sahibi/hırsız rolünde Michael Gambon (Albert), Albert'in karısı rolünde Helen Mirren (Georgina) ve onun aşığı olarak Alan Howard (Michael) canlandırmıştır. Filmin neredeyse tamamı restoran bünyesinde geçerken diğer mekanlarsa Michael'in kitaplarla dolu evi ve bulaşıkçı çocuğun kaldığı hastanedir.

\section{1. İçerik}

Film, tiyatro oyunlarında olduğu gibi kırmızı bir perdenin iki yana doğru açılmasıyla başlar ve yine aynı şekilde perdelerin kapanmasıyla sona erer. Filmin mekanları, oyuncuların performansları ve

2 The Banquet of the Officers of the St George Militia Company in 1616, tuval üzerine yağlıboya, 175X324, Frans Hals Museum, Haarlem, Hollanda. 
Jean-Paul Gaultier imzalı abartılı kostümleri de bir tiyatro sahnesini andırmaktadır (Saskia Boddeke \& Peter Greenaway Projects). İngiliz olan Albert, "Hollandalı” adında, başında Fransız şef Richard'ın bulunduğu bir restoran işletmektedir. Hollandalı isimli restoranda Fransız mutfağına ait yemeklerin sunulmasındaki absürtlük ve tezat filmin genel konstrüksiyonu hakkında önbilgi verir. Filmde "düzgün işlemeyen"e dair bir diğer örnek mutfaktır. Burası, Albert’in dilinden düşürmediği temizliğin çok uzağındadır. Üstü çıplak aşçıların, etrafa saçılmış yiyecek parçalarının ve havada uçuşan ördek tüylerinin olduğu mutfakta kaos hakimdir ve mutfaktan çok mezbahayı andırmaktadır. Yeni hazırlanan ışıklı restoran tabelasında Albert'in soyadı olan "Spica" yerine yanlışlıkla "aspic" yazılmıştır. İngilizcede Aspic'in anlamıysa, Albert'in insani değerlerden uzaklığını ve basitliğini imlercesine "pelte halindeki et suyu"dur (Cambridge Dictionary). Yazının diğer kısmında aşçının soy ismi olan "Boarst” yazması gerekirken Georgina'nın "t” harfini kapatacak şekilde sahneye yerleştirilmesiyle "erkek yaban domuzları" anlamına gelen "Boars" kelimesi ortaya çıkmıştır (Cambridge Dictionary). Tabeladaki harflerin ışığının yanmaması ve ardından elektriklerin kesilmesi restorandaki işleyişin bozuk olduğunu gösterir. Filmin ilerleyen sahnelerinde restorandaki çürümenin ve kokuşmuşluğun somut göstergeleri olarak çürümüş, kurtlanmış et parçaları da görünür olmaya başlar.

Hedonist Albert, her akşam restoranına gelir ve restoranın en büyük masasında, çevresine topladığı kişilere cinsellik, Fransızca, sanat, mutfak kültürü gibi çeşitli konularda ahkam keserek ziyafet verir. Yanında oturan ve sessizce kaderini kabullenmiş olan karısı Georgina'yı sık sık sözlü ve fiziksel olarak taciz eder. Masasındaki diğer kişileri de aşağılayıp, onları küçük düşürür. Georgina, bir akşam karşı masalardan birinde oturan Michael ile kaçamak bir ilişki yaşar. Iliş̧kilerinin zamanla aşka dönüşmesi, aşçının da bu çifte yardım etmesiyle filmin gerilimi tırmanır. Albert'in çevresindekilere karşı uyguladığı şiddetin dozunun arttırmasıyla hem müşterilerin hem de Albert'in masasındaki konukların sayısı günden güne azalır.

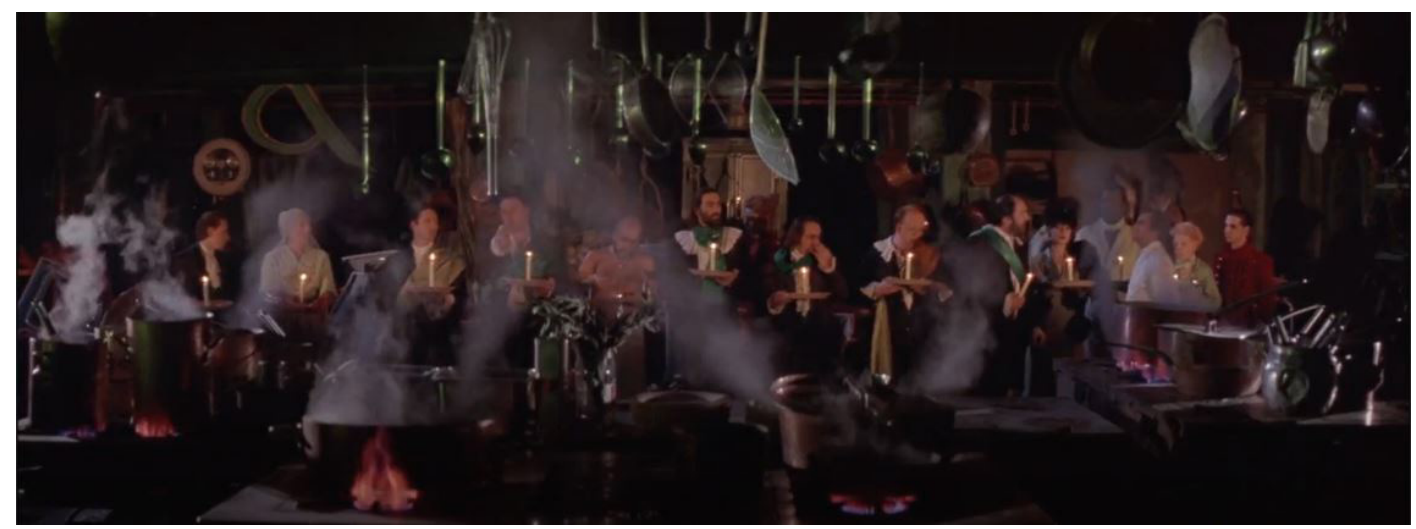

Görsel 2: Sahne aydınlatması ve mizansenle aşçı ulvi bir aura kazanır

Filmde serpiştirilmiş halde birçok dini referanslı sahne vardır. Bu sahneler mutfak ve mutfak çalışanlarıyla ilintilidir. Aşçı Richard rahip, diğer mutfak çalışanlarıysa onun yardımcıları gibidir. Aşçı, restoranın elektrikleri kesildikten sonra elindeki mumla etrafındakilerin mumlarını yakar. Bu sahnenin aydınlatması ve aşçının ağır hareketleri ona ilahi bir karakter, mekanaysa ulvi bir aura kazandırır (Görsel 2). 


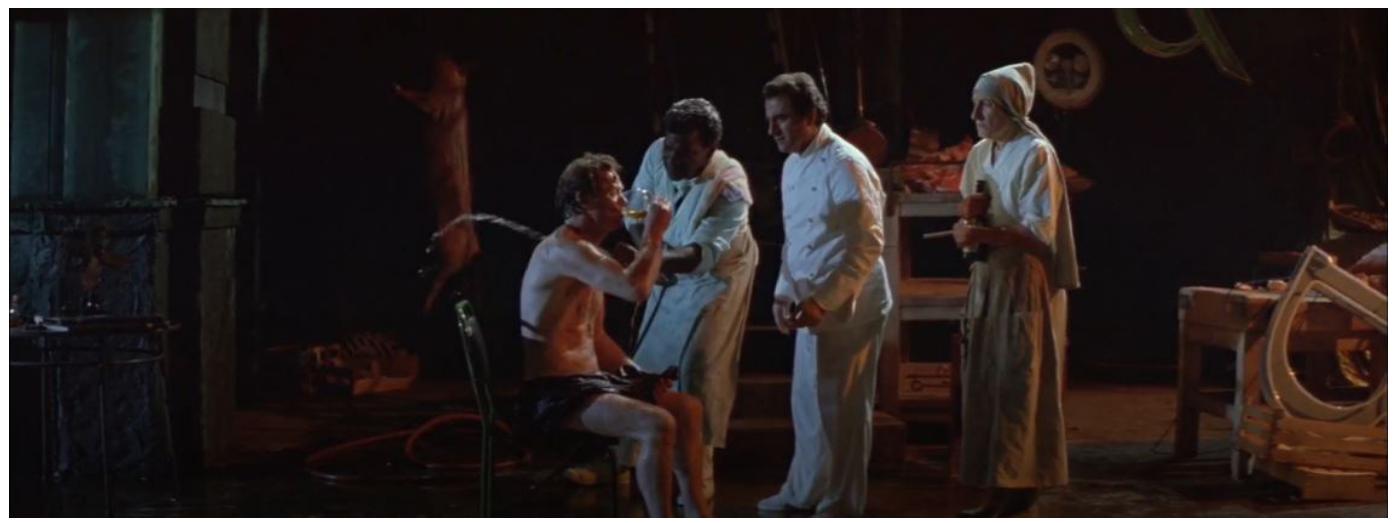

Görsel 3: Hristiyan imgelerinin yer aldığı arınma sahnesi

Albert ve adamları tarafından dışkıya bulanan adam, vaftiz ve arınma göstergeleriyle yine aşçının liderliğinde yıkanır, elinden şarap içer. Arkasında bulunan mutfak görevlilerinin kıyafet biçimleri ve duruşları kilise görevlilerine benzer (Görsel 3). Bulaşıkçı çocuğun yer aldığı hastane sahnesinde ise bu kez hasta bakıcılar aynı temsili üstlenir. Çocuğun söylediği "yıka beni” sözleriyle başlayan şarkı güftesiyle arınma amacıyla edilen bir duaya benzerken işitsel olaraksa kiliselerdeki çocuk korolarını çağrıştırır. Filmin son sahnesinde Albert, dikdörtgen bir masa üzerinde "et" ve şarabı tükettikten sonra Georgina'yı vurmaya kalkışır. Ancak yanındaki adamı ona ihanet ederek silahı karşı tarafa fırlatır ve Albert vurularak ölür. Masanın diğer tarafındaysa dışkı yedirilen adamdan, yanağına çatal batırılan kadına kadar Albert tarafından eziyet görmüş kişiler yer alır. Filmin önceki kısımlarından farklı olarak burada herkes cenaze törenine gelmiş gibi siyah giyinmiştir. Masanın biçimi, Albert'in konumu, şarap, et ve ihanetle Greenaway, Hz. İsa'nın son akşam yemeğini yeniden canlandırmış gibidir.

\subsection{Biçim}

Film, teatralliğinin yanı sıra kamera hareketleriyle seyirciyi kişisel bir sergide, Greenaway'in Aşçı, Hırsız, Karısı ve Aşı̆̆ı konulu sergisinde gezdirir. Demiray'ın (2014) da dikkat çektiği üzere kamera, "büyük bir tabloyu sağdan sola veya soldan sağa tarayan göz hareketleri çizdiği anlarda oldukça dikkat çekici bir sunum" sergiler. Sergilerde tabloların çoğunlukla yan yana konumlandırılmasıyla göz, bir tablodan diğerine geçmek için yatay doğrultuda hareket eder. Greenaway'in sıraladığı mekanlar da kameranın bir mekandan diğerine kaydırılması sonucunda bu hareketi taklit eder ve seyirci sanki tablolar arasında göz gezdiriyormuşçasına izler filmi. Uzun plan sekanslarla tabloya bakılıyormuş hissi uyandırıır. Filmde zoom gibi insan gözünün yapamayacağı yapay hareketler yer almaz. Filmin yakın plana girdiği tek sahnede, janr resimlerinde insanların her türlü duygu ve durumda resmedildiği gibi, Georgina'nın yüzü görülür. Film boyunca sessiz, donuk, bıkkın görünen Georgina, "Sana anlatmalıyım, senden başka kime anlatabilirim ki?" diyerek geçmişinden ve yaşadıklarından bahseder. Yakın planda Georgina'nın gözyaşlarına tanık olunur. Filmin sahneler arası geçişleri yine insan gözüne uygun olarak, göz kırpma hareketinin benzeri şekilde kesmelerle yapılır. Georgina ile aşığının sevişmesiyle mutfak tezgahındaki sebzelerin kesilmesi paralel kurguyla verilir. Bıçağın keskinliği ve hızı, hızlı kurguyla sevişme anının gerilimini ve duygusunu yükseltir. Çiftin sağında ve solunda yer alan ekmeklerin biçiminin vajinayı andırmasıyla sahne sembolik olarak da desteklenir. 


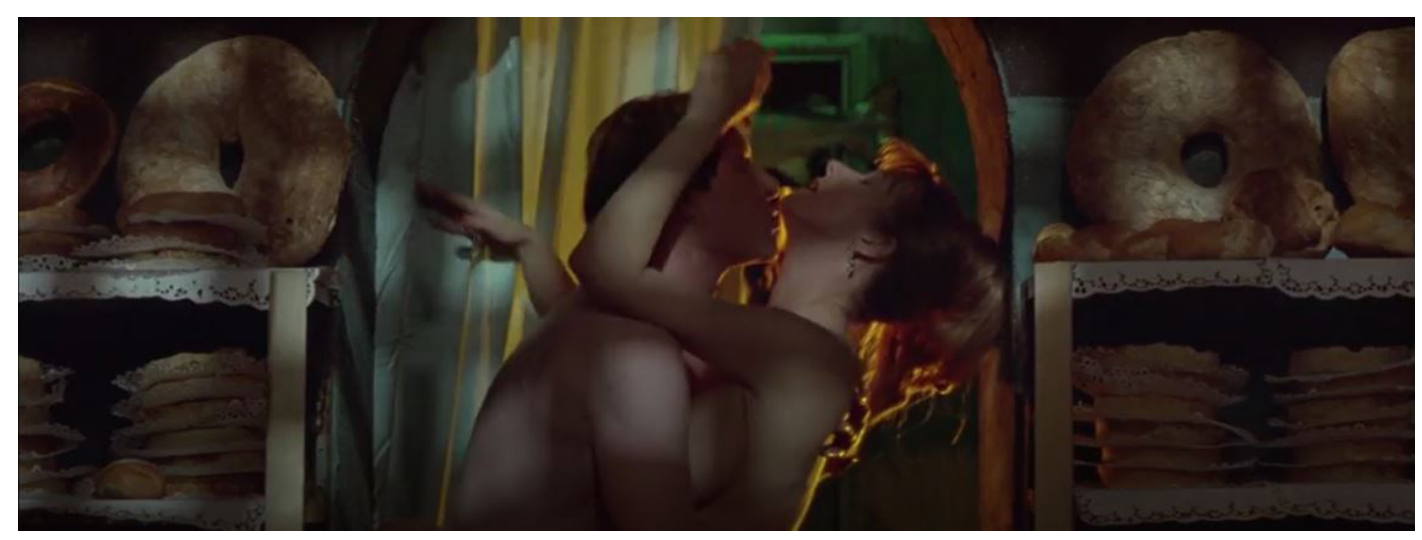

Görsel 3: Sevişme sahnesinde yer alan sübliminal imgeler

Filmde barok üslupta kullanılan ışık, resimlerdeki gibi figürleri canlandıran, heyecan katan bir unsur olarak kullanılır. Yakalanan kontrast ile filmdeki çatışma aydınlatmayla desteklenmiş olur. Tuvalet kapısının açılmasıyla restorandan, beyazın hakim olduğu tuvalete doğru kırmızı ışık vurur. Böylece tuvalette oluşan pembemsi renk, barok üsluptaki renk karışımlarını hatırlatır. Dönemin taşkınlığı ve yağlıboya resimlerde renklerin birbiri içerisinde kaynaştırılarak eritildiği üslupla paralellik gösterir. Yönetmenin, barokla uyuşmayan tek tercihi Hollanda barok döneminde görülen asimetrik eğilimdir. Bunun yerine Greenaway, Stanley Kubrick veya Wes Anderson'da olduğu gibi simetrik mizansenler kurar.

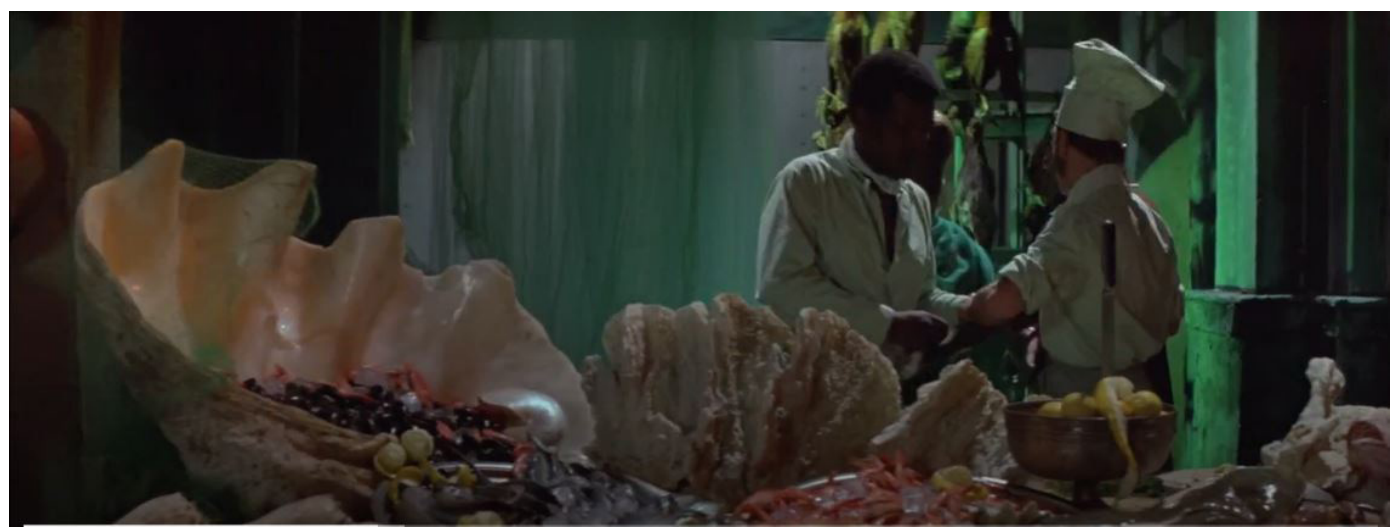

Görsel 4: Botticelli'nin Venüs'ün Doğuşu tablosunu andıran mizansen

Tablo-planlar için yönetmen daha çok mutfağı tercih eder. Kimi zaman üstteki resimde görüldüğü üzere Venüs'ün Doğuşu gibi klasik eserleri kimi zamansa dondurulmuş hayvanlar, deniz ürünleri ve sebze-meyvelerle Hollandalı ressamların natürmortlarını canlandırılır. Filmi parçalara bölen “menü”lerin süslemelerinde de yine natürmortlardan faydalanılır. Aşçıların tezgahları, sofra konulu tabloları hatırlatırken birçok ünlü resim, filmin karakterleri ve dekorlarıyla Greenaway tarafından yeniden üretilir. Garaj sahnelerindeyse kadrajın sağında ve solunda kapakları açık şekilde duran kamyonetler çerçeve içinde çerçeve yaratır. 


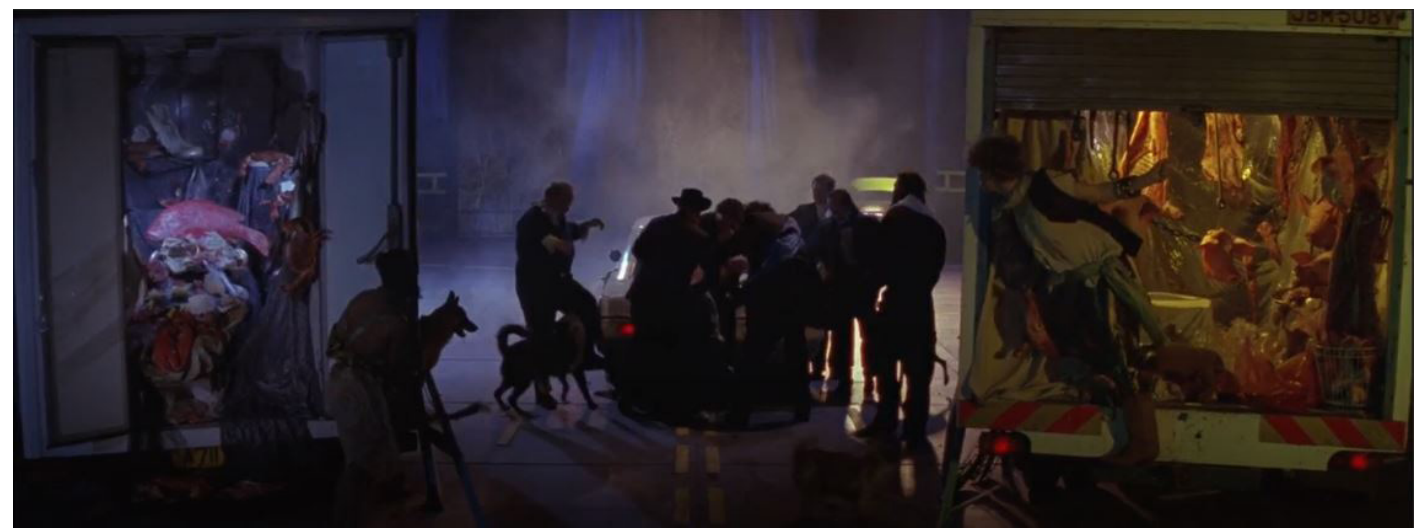

Görsel 5: Kamyonet kapaklarıyla sağlanan çerçeve içinde çerçeve tekniği

\subsection{Renkler ve Mekanlar}

Bir tablodan renkler çıkarıldığında geriye ne kalırsa, Aşçı, Hırsız, Karısı ve Aşığı filminden de geriye o kalır. Ressam kimliğini filmlerinde sergileyen yönetmen, renkleri salt estetik amaçlı kullanmaz. Görünenin ötesinde, renklerin psikolojik olarak yarattığı etkileri göz önünde bulundurarak öyküsünü örer. Renkleri anlamlarıyla kullanarak filmine bir katman daha oluşturan Greenaway, filminde renkmekan ilişkisi kurmuştur. Bu bağlamda Aşçı, Hırsız, Karısı ve Aşığı'nda dört ayrı mekan ve dört ayrı renk bulunmaktadır.

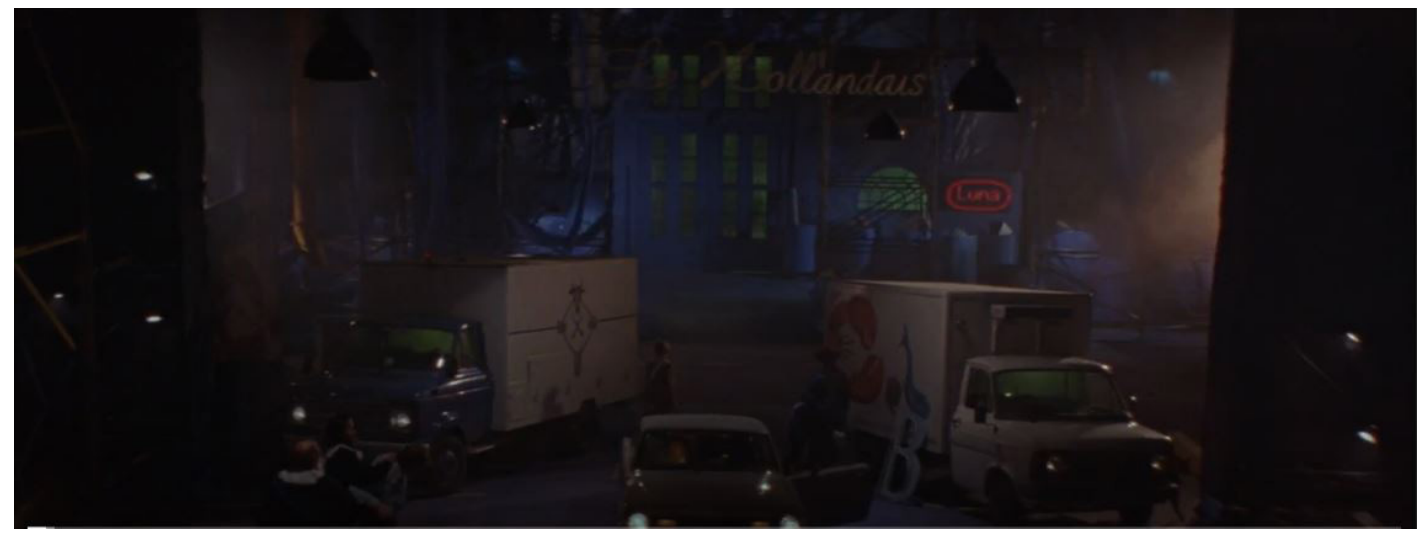

Görsel 6: Tiyatro sahnesini andıran garaj mizanseni

Film yatay düzlemde garaj, mutfak, restoran ve tuvaletler şeklinde sıralanır. Bu sıraya uygun olarak öncelikle garaja bakıldığında bir tiyatro sahnesini andırdığı görülür. Tepeden sarkan lambalar iç mekan etkisini arttırırken, kenarlarda görülen profilden iskeleler tiyatrolardaki sofitaları hatırlatır. İlk sahnenin büyük kırmızı iki kanatı perdeyle ve iki kişinin yardımıyla açılması bu savı destekler. Yönetmenin bu mekan için seçtiği mavi renk, Mustafa Sözen’in (2003, s. 85) belirttiği üzere iç mekanlarda yoğun olarak kullanıldığında endişe ve tedirginlik duygusu uyandırır. Garajda geçen sahneler düşünüldüğünde akla ilk olarak Albert ve adamlarının alacaklı oldukları adamı soyup işkence ettikleri ve Albert'in Georgina'yı darp edip arabaya bindirdikten sonra tecavüz ettiği sahneler gelir. Şiddetin çeşitli hallerinin gösterildiği garajda, mavi renk soğuk ve tekin olmayan bir atmosfer oluşturur. Kandinsky (2010, s. 82), sıcak renklerin seyirciye yaklaşırken soğuk renklerinse uzaklaştığını yazar. Bu nedenle film evreninin "çıkış" mekanı olan garajın maviye bürünmesi filmden ve mekandan ayrılma duygusunu destekler. Diğer taraftan gökyüzünün ve denizin rengi olmasıyla yolculuğu ve özgürlüğü çağrıştırır. Mavinin bu anlamı Michael ve Georgina'nın kamyonete saklanarak özgürlüklerine, aşklarını yaşayacakları güvenli bir bölgeye doğru Albert’ten kaçtıkları sahnede 
gerçekleşir. Keskinok (Keskinok), iki karşıt rengin bir araya gelmesiyle renkler arasında egemenlik savaşının başladığından, bu nedenle bulundukları ortamda rahatsız edici bir etki yarattıklarından bahseder. Yönetmen, gerilimi kuvvetlendirmek amacıyla mekanın ana rengiyle beraber zıddını da kullanır. Çağan'ın (aktaran Kırık, 2013, s. 74) yazdığına göre turuncu, gergin durumlarda sinir kat sayısını arttırmaktadır. Bu nedenle mavinin yanında zıddı olan turuncu rengin, kapısı açık olan kamyonetin (sahnenin sağındaki) içinden etrafa yayılması sağlanır. Albert ve Georgina garaja girdiklerinde Albert'in gömleği, Giorgina'nın ise şalı maviye dönüşür.

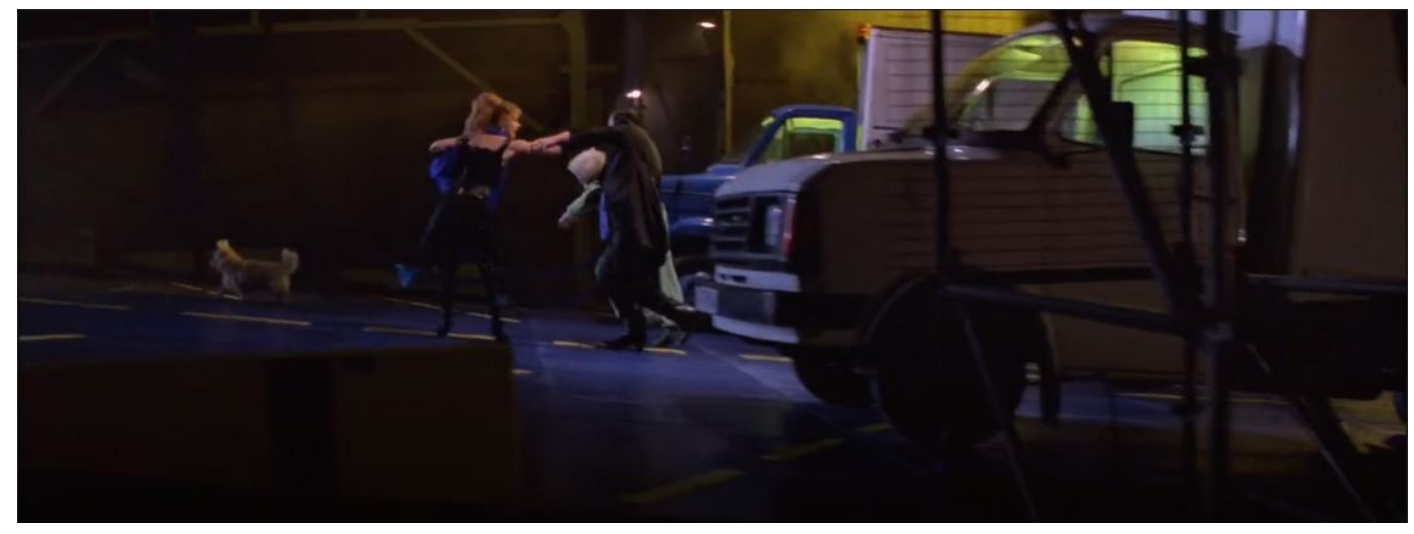

Görsel 7: Georgina'nın şalı ve Albert'in gömleğiyle kravatı, maviye dönüşür

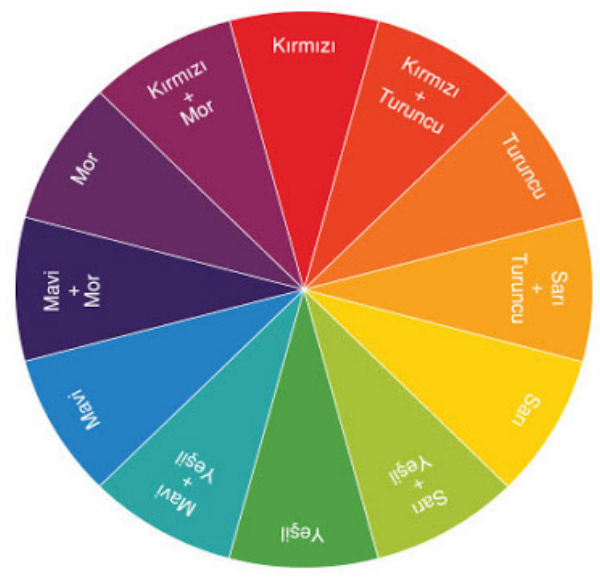

Görsel 8: Renk Çarkı

Garajdan sonra gelen mutfakta tercih edilen renk yeşildir. Mutfak, yeşil renkteki ışıklarla aydınlatılırken kontrastı olan kırmızı ise yanan fırın ve çevredeki et parçalarıyla gösterilir. Yeşil, tıpkı bahar aylarında olduğu gibi Halse'nin (aktaran Mazlum, 2011, s.133) de belirttiği üzere umudu ve verimliliği simgeler. Umut, aşçı ve diğer çalışanlarla beraber işçi sınıfında, verimlilikse mutfakta yapılan üretimde yansımasını bulur. Aynı zamanda Sözen (2003, s.102), yeşilin tüm renkler içinde en sessiz renk olduğunu ve neşe, hüzün, hırs gibi herhangi bir duyguya çekilemediğini yazar. Aşçı Richard'ın Albert'e karşı takındığı tavra bakıldığında hiçbir zaman duygusal bir tepki vermediği görülür, o tüm soğukkanlılığıyla işini icra eder. Mutfağa giren Albert ve Georgina'nın kıyafetleri mekana uygun olarak yeşil renge dönüşür. 


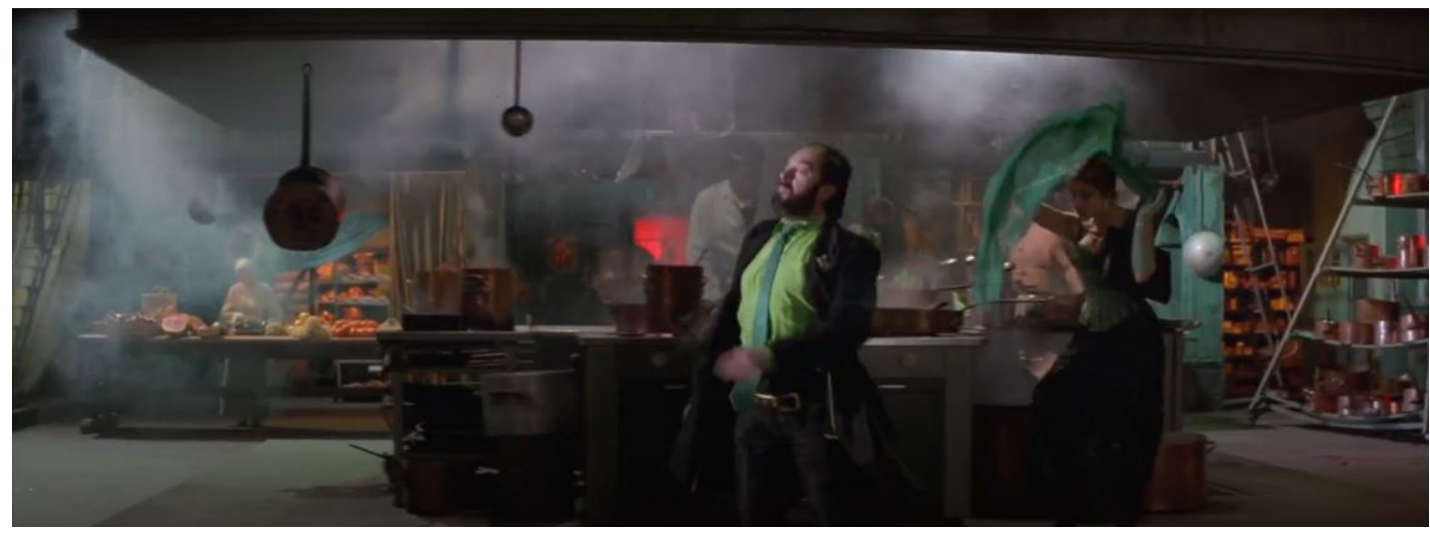

Görsel 9: Georgina'nın şalı ile Albert'in gömleğiyle kravatı yeşile dönüşür

İki ayrı otorite olan aş̧̧ı Richard ile restoran sahibi Albert arasındaki çatışma, onların ait oldukları mekanların yan yana konumlandırılmasıyla ve renk seçimleriyle desteklenir. Aşçının yönetimindeki üretime dair olan mutfak yeşilken, Albert'in kurallarının geçerli olduğu ve tüketimi simgeleyen restoran yeşilin kontrastı olan kırmızı renktedir. Filmde ağırlıklı olarak tercih edilen restoran bölümü, kullanılan renk ve dekorlarla da filmin en baskın mekanıdır. Yüksek duvarlardan mekanı boydan boya kaplayan halıya, kapılardan perdelere dek buradaki her şey kan kırmızısıdır. Renkler içinde en yüksek dalga boyuna sahip olan kırmızı, Sözen'in de belirttiği gibi kalp atışlarını hızlandırmakta ve adrenalin hormonunun artmasına neden olmaktadır. Fizyolojik olarak heyecan uyandıran bu renk aynı zamanda içgüdüsel ve sinirli davranışları ortaya çıkararak, irade hakimiyetini kaybettirmektedir (Sözen, 2003, s.81). Rengin bu etkisi Albert ve masasındaki adamlarında açıkça görülür. Üster (aktaran Kırık, 2013, s. 74), kırmızının egoizm, sahip olma ve kendini tatmin etmeyle ilişkili olduğunu belirtir. Bu nedenle Albert'in sahip olduğu restoranın baştan aşağı kırmızı olması şaşırtıcı değildir. Kontrast oluşturmak içinse çiçekler ve Michael'in kitapları gibi dekorlarla mekana yeşil renk serpiştirilmiştir. Neredeyse restorana gelen herkesin kıyafetleri kırmızı ve siyahtan oluşmaktadır.

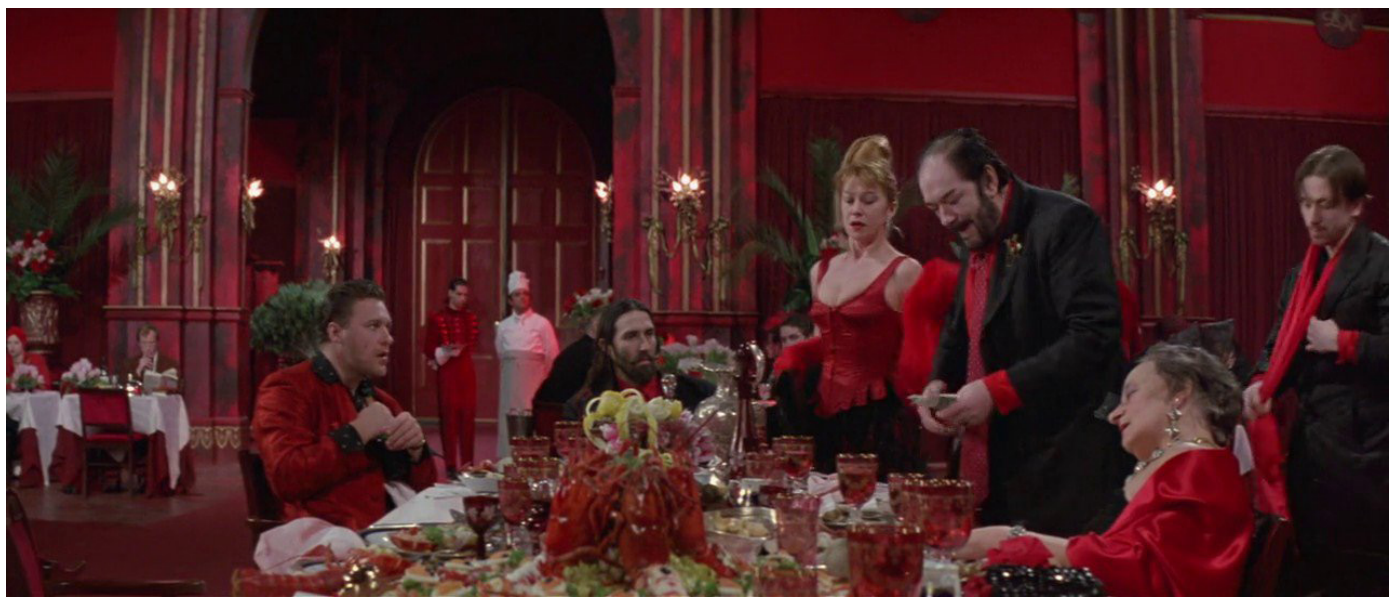

Görsel 10: Restorandaki hakim renkler; kırmızı ve siyah

Son mekan ise beyaz hakimiyetindeki tuvaletlerdir. Diğerlerinin aksine burada zit renk tercih edilmemiştir. Böylece hem beyazın saflığı korunmuş hem de diğer mekanlara oranla çatışmanın gücü azaltılmıştır. Burası, restoranın karmaşasından uzakta, fiziksel ve ruhsal olarak rahatlama imkanı sunar. Kandinsky (2010, s.88), beyazı "tüm renklerini yitirmiş bir dünya"ya benzeterek rengin sessizliğine dikkat çeker ve ekler; "Bu, ölü değil, olanaklara gebe bir sessizliktir." Öyle ki tuvaletin kapısı açıldığında restorandan içeriye yansıyan kırmızı ışık bile masumlaşarak pembeye dönüşür. Beyazın olanaklara gebe yapısıysa Georgina ve Michael'ın sevişmesiyle yaşanan kırılmadır. Burada 
da Georgina’nın kırmızı eldivenleri ve Albert'in kırmızı gömleği tuvalete geçince beyaza dönüşür.

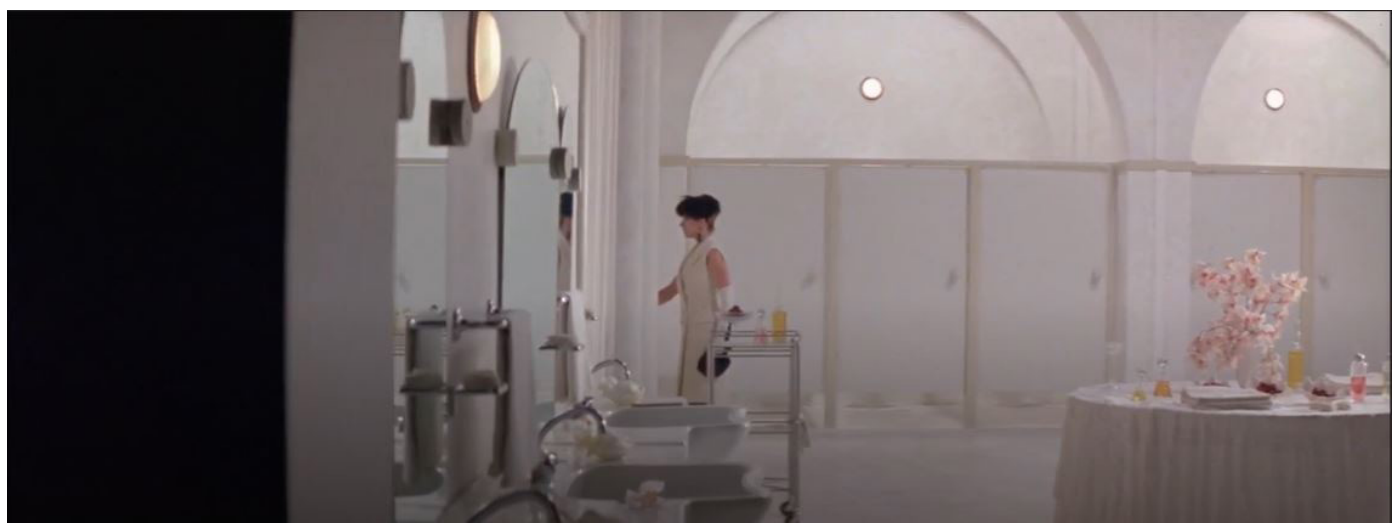

Görsel 11: Georgina'nın kıyafetleri beyaz renge dönüşür

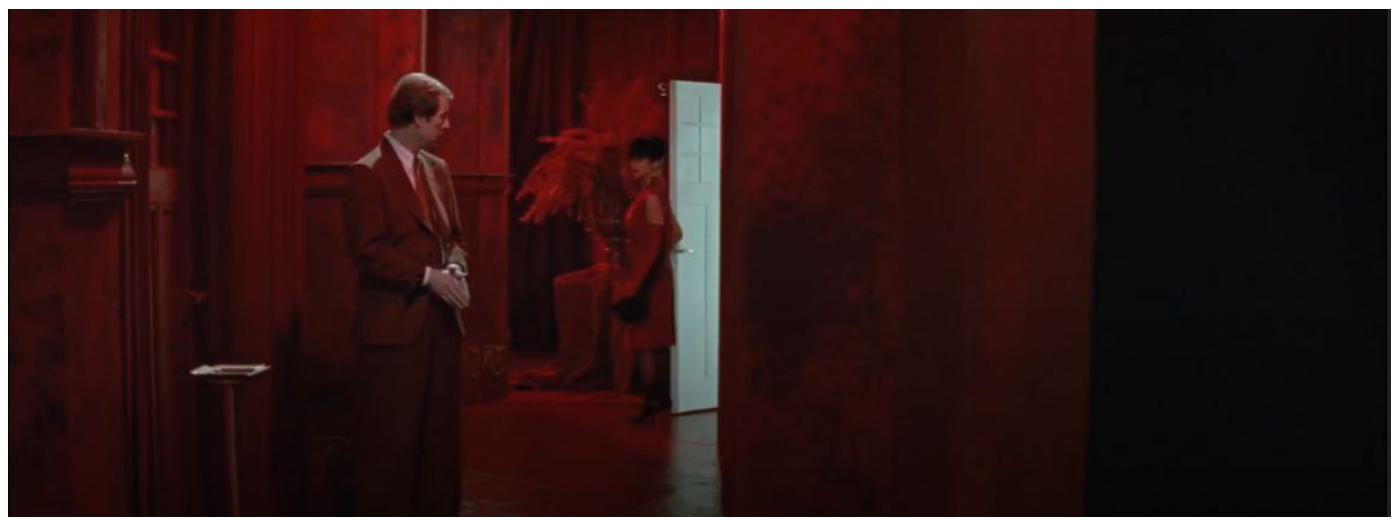

Görsel 12: Georgina, restoran bölümüne geçtiğinde kıyafetleri kırmızıya dönüşür

Mekanların yanında karakterlere seçilen kostümlerin renkleri de kodlar içermektedir. Kahverengi takım elbise giyen Michael, bu renkle topluluğun içinde sıradanlaşıp kaybolup gitmesi gerekirken herkesin kırmızı ve siyah olmasından dolayı ayrıksı durur. Tıpkı cahil bir toplumda ender bulunan aydın kesim gibi. Sadece kıyafeti değil yaşadığı daire ve kitaplığı da kahverengi ağırlıklıdır. Sun'un (aktaran Kırık, 2013, s.76) işaret ettiği üzere kahverenginin psikolojideki etkisi güven duygusudur. Bu nedenle film boyunca kendine dair hiç konuşmayan Georgina, Michael'a güvenerek geçmişini ve yaşadığı eziyetleri samimiyetle anlatır. Sözen (2003, s.94), kahverenginin en ayırt edici özelliğinin "(...) yaşanan gerçek zaman ile "anı"laşmış gerçekliği birbirinden ayırmasıdır." der. Bu yanıyla Michael, Georgina’nın yaşadıklarıyla yüzleşmesini ve bugünü düşünmesini sağlar.

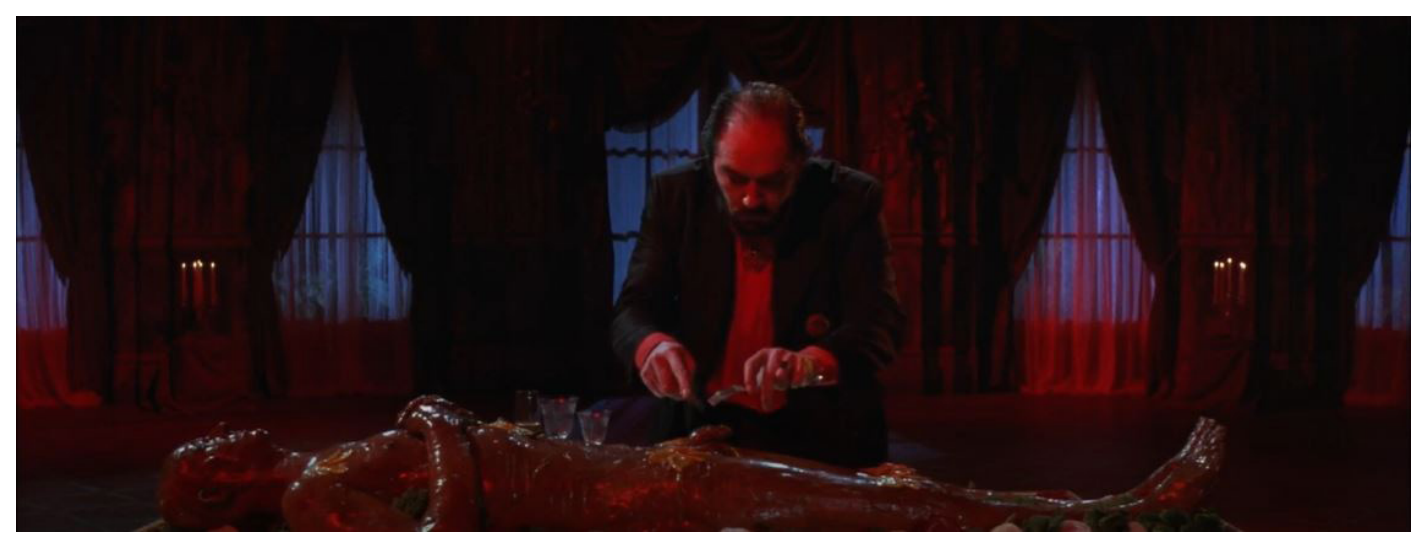

Görsel 13: Michael, öldükten sonra bile kahverengi ile temsil edilir

Michael'ın, filmin sonunda masadaki pişmiş halinde bile kahverengimsi bir rengi vardır. Kahverengiyi 
meydana getiren ana renklere bakıldığında yeşil, kırmızı ve siyah olduğu görülür. Michael'ın (işaret ettiği entelektüel bilinçle) son sahnede pişmesi, yası simgeleyen siyah rengin beraberinde yeşili (aşçıyı, proleter sınıfını) ve kırmızıyı (Albert'i, kapitalizmi) bir araya getirir ve çarpıştırır. Dikkat çeken bir başka öğe ise mekana göre Albert ve karısının kıyafetleri renk değiştirirken, Michael ve aşçının kıyafetlerinin hep aynı kalmasıdır. İşçi sınıfının ve aydın kesimin hangi ortamda, hangi toplumda olursa olsun rolü büyük oranda belirlidir. Ancak otoriteler ve halk kolay manipüle edilebilir, yönlendirilebilir ve bulunduğu ortamın sosyal, ekonomik ve politik yapısına göre şekillenebilir.

\subsection{Karakter Temsilleri}

Peter Greenaway, görsele dair yarattığı bu sanatsal harmanının beraberinde bir sistem eleştirisi sunar. Restoranda geçen mikro ölçekteki kapitalist hiyerarşiyi çözümleyip makro düzeyde anlamlandırabilmek adına filmde yer verilen karakter temsillerini incelemek önemlidir.

Restoranın sahibi Albert, içgüdülerini kontrol edemeyişiyle ilkel, yemek ve cinsel oburluğuyla hedonist ve ani duygu geçişleriyle histerik bir karakterdir. Albert, eşine ve masadaki adamlarına sürekli "ellerine yıka", "sifonu çek", "klozeti sil" ve "tırnaklarını göster" gibi temizliğe dair uyarılarda bulunur ve onları kontrol eder. Tüm bu sözde titizliğe hatta kirlenme paranoyalarına rağmen Albert'in ağzından küfürler, hakaretler ve içinde dışkı, idrar, istifra gibi kelimelerin geçtiği cümleler eksik olmaz. Bunların yanında Albert, mutfak kültüründen sanata, cinsellikten Fransız diline kadar bir çok farklı konuda beyanat verir. Ancak söylediği "Birbiriyle alakasız şeyleri birleştirmeye sanat denir." cümlesinde olduğu gibi kendinden emin tavırlarla sarf ettiği sözlerinin içi boştur. Narsist bir kişilik sergileyen Albert, cinsellik ve beslenme gibi dürtüleriyle şiddet eğilimini kontrol edemez. Yüksek sesle konuşarak kaba tavırlar sergiler. Onun bu ilkelliği, ilk sahnedeki köpeklerle paralellik gösterir. Albert ve adamları, işkence ettikleri adamın üzerindeki kıyafetleri parçalayıp onunla boğuşurken hemen yanlarındaki köpekler de bir et parçasını çekiştirerek kavga ederler. Biri insanlardan biri köpeklerden oluşan bu iki grubun tavırları ve hareketleri şaşırtıcı derecede benzerdir. Bir diğer örnek Georgina ile Michael'ın tuvalette seviştikten sonra Albert'in tuvalete geldiği sahnede görülür. Albert, bir hayvanın koku kabiliyetine sahipmişçesine az önce sevişmiş olan Georgina'nın bedeninden salgılanan feromonun kokusunu alır ve "Terin hoş kokuyor. Ellerini yıka, seni öpeceğim." diyerek karısıyla yakınlaşmaya başlar.

Albert, filmde despot bir otoriteyi simgeler. İnsanları çırılçıplak soyup hayvan dışkısına bulayan, haraç toplayan, çevresindekilere işkence eden bir mafya babasıdır. Restoranın sahibi olmakla yetinmez, oradaki tüm insanların da sahibi gibi davranır. Bir restoranda olabilecek kuralların dışında özel yaşama dair keyfi kurallar da koyar. İlk sahnede vücuduna köpek dışkısı sürdüğü adama "Kuralları öğrenmelisin!" diye bağırır. Karısına "Sigara içmek kadınlara yakışmıyor." diyerek hem cinsiyetçi bir tutum sergiler hem de karısının yemekten ve kendisinden başka bir şeyden haz almasına mâni olur. Georgina'nın uzun süre tuvalette kalmasından sonra "Kendi kendini mi tatmin ediyorsun? Burası benim mülküm, buna hakkın yok." ifadesiyle benzer yasaklarını sürdürür. Cinsiyetçi sözlerinin bir başka örneğiyse bulaşık yıkamanın kadın işi olduğunu söyleyip, bulaşıkçı çocuğun cinsiyetini sorguladığı sahnede görülür. Albert, nobranlığını karısı, masasındaki yakınları, restoran çalışanları hatta müşterileri üzerinde bile gösterir. Müşterileri restorandan kovar veya darp eder. Masasındakileri aşağılar, yemek yemeye zorlar. Karısına sık sık sözlü veya fiziksel tacizde ve tecavüzde bulunur. Albert'in faşizan eylemleri sadece cinsiyetle ve statüyle sınırlı kalmaz. Ellerini yıkaması için leğen getiren Çinli görevliye Çin yemeklerini sevmediğini söyleyerek su dolu leğeni 
görevlinin üstüne döker, Yahudi olan Michael hakkında "Küçük sünnetli puşt!" diyerek bahseder. Albert ve aşçı arasında geçen diyalog ise şöyledir:

"Kaliteyi ben temsil ederim. Ben kalite ve koruma sunarım."

"Kime ve neye karşı koruma?"

"Adamlarımın acımasız sinirlerine karşı. Ani yemek zehirlenmelerine, farelere ve halk sağlığı müfettişlerine karşı."

Albert'in bir otorite olarak sunduğu koruma, verdiği cevaptan açıkça anlaşıldığı gibi aslında kendinden doğan zararlara karşıdır. Albert, varlığıyla zararıdır. Filmde kendisinden yiyecek almayan diğer restoranlara zehirli gıdalar satarak oradaki müşterileri zehirler ve restoranların sahiplerinden haraç alır.

Albert, Hollandalı burjuvalar gibi paraya ve gösterişe düşkündür. Karısını "Harika vücudu, altın gibi kalbi vardır." sözleriyle fetişleştiirken kendisi de "Harika param, alın gibi kalbim vardır." diyerek parasıyla tanımlar. Restoran için bardak siparişi verirken "Bir sürü bardak istiyorum, gösterişli görünüyor." diyerek bir amaca hizmet etmeyen, salt biçimsel ve gösterişe dayalı eylemlerini açığa vurur. Görünüm onun için o denli önemlidir ki masasındakileri iyi giyinmemeleri halinde bedelini ödemekle tehdit eder. Maddi gücünü ve şaşaasını restoranına yansıtmak için restoranın altın rengi boyanmasını ister. "İşim para, zevkim yemek yemek." sözleriyle kendisini basitçe para ve tüketim üzerinden tanımlar. Albert'in tüketim tutkusu Kanibalizm'e kadar uzanır. Michael'ı yemek istediğini söyler ve nitekim filmin sonunda da yer. Albert'in de filmin de sonunu getiren bu "insan yeme" boyutuna varan sapkın davranışın ardından Albert kendi silahıyla vurulur. Kendi seçim ve davranışlarıyla bu sona doğru sürüklenmiş, yine kendine ait olanla perdeden çekilmiştir.

Georgina, diktatör bir yöneticinin, Albert'in tahakkümü altındaki halkı temsil eder. Aklı başında, kültürlü bir karakter olan Georgina, çevresinde olup bitenlerin farkında olmasına rağmen Albert'e karşı gelmez. Kendisine karşı yapılan tüm haksızlık ve ahlaksızlıklara sessizce boyun eğer. Georgina'nın ilgisini kocasının zıddı bir karakterde olan Michael çeker. Michael'ın kibar ve entelektüel tavırları onu etkiler ve kısa sürede birliktelikleri aşka dönüşür. Michael'ın kütüphanesini görünce Georgina, "Bu kadar kitabı ne yapacaksın yiyecek misin?" sorusuyla bilimden ve düşünceden ne kadar uzak kaldığını gösterir. Düşünce yapısının hayatını beraber geçirdiği Albert'inki gibi şekillenmesi, yönetici ve toplum ilişkisini anlamlandırmada önemli bir örnektir. Michael'la vakit geçirdikçe bu kez onun düşün yapısına yaklaşan Georgina, toplumun aydın kesimini temsil eden Michael'dan aldığı güç ve cesaretle Albert'in karşısında durarak onun otoritesini devirir. Albert'in "bir Fransız devrimi" benzetmesinde bulunduğu karısı, mutfak çalışanlarını arkasına alarak devrimi gerçekleştirir. Filmin son sözünü, Albert'in (dolayısıyla diktatör yönetimlerin) yönettiği topluluğu, insanları yiyip bitirmesinin en somut halini imlercesine Albert'i silahıyla vuran Georgina söyler: "Yamyam!" Böylece Albert'in yaptıklarına maruz kalan bir halktan onu yaptıklarıyla yüzleştirebilen bir halka dönüşüm gerçekleşmiş olur.

Aşçı Richard ise mutfaktaki çalışanlarıyla beraber proletaryayı sembolize eder. Tıpkı Georgina gibi Albert'in hukuksuzluğunun o da farkındadır. Restoran tabelasının denendiği sahnede elektriklerin kesilmesiyle aşçı, sarkastik biçimde "Bay Spica'nın cömertliği sağ olsun, her yer karanlık. Elektrik yok, ışık yok." der. Bu esnada vücuduna dışkı sürülüp darp edilen adama yapılan kesmeyle buradaki ışığın-karanlığın soyut manada kullanıldığı anlaşılır. Richard, Albert tarafından "Bensiz sen bir yabancısın. Buralarda fazla hayatta kalamazsın" şeklinde tehdit edilse de Albert ona dokunamaz. 
Çünkü kapitalizmi temsil eden Albert'in varlığı, aşçı ve mutfak çalışanlarının yani işçilerin üretimi ile mümkündür. Aşçı olmazsa mutfak olmaz, mutfak olmazsa Albert'in himaye edeceği bir alan kalmadığından otoritesi yıkılmış olur. Bu nedenle aşçının gücünün farkında olan Albert, bir tek ona dokunamaz. Albert'in bu bağlıı̆̆ının farkında olan aşçı Richard, onu eleştirmekten çekinmez. "Dekora harcanan para kadar, yemeğe harcanırsa yemek zevkiniz gelişir." diyerek Albert'in kültürel birikimsizliğini ve bunu örtmek için kullandığı gösteriş tutkusunu eleștirir. Başka bir sahnede ise açlığını bastırması adına kurduğu "Ceketinizin 3. düğmesini de iliklemelisiniz. İçinizdeki boşluğu daha az hissedersiniz." cümlesi Albert'in insani eksikliğinin, göstereceği saygıyla bir nebze olsun kapanabileceği fikrini verir. Albert'in pahalı yiyecekleri tüketmesinde beslenme güdüsünün ötesinde "ölümü yeme, yenme" arzusu olduğunu da yine aşçı açıklar: "Siyah yemek yemek, ölümü tüketmek gibidir. Yani 'ölüm, seni yiyorum işte' gibi. Siyah mantar ve havyar en pahalı olanlarıdır. Ölüm ve doğum. Son ve başlangıç."

Halkı temsil eden Georgina'ya aşçı daima yardımcı olur. Ona özel yemekler sunar, kaçak ilişkisini yaşaması için onu gizler. Georgina, Albert'e karşı planladığı devrimi gerçekleştirmek için yine işçilerden, aşçıdan yardım ister. Aşçı, üzerine düşeni yapar ve Albert'in "son akşam yemeği"ni hazırlar. Son sahnede Albert'in silahı önce aşçının eline geçmesine rağmen, Albert'in diktatör rejimini deviren güç olma rolünü Georgina'ya bırakır.

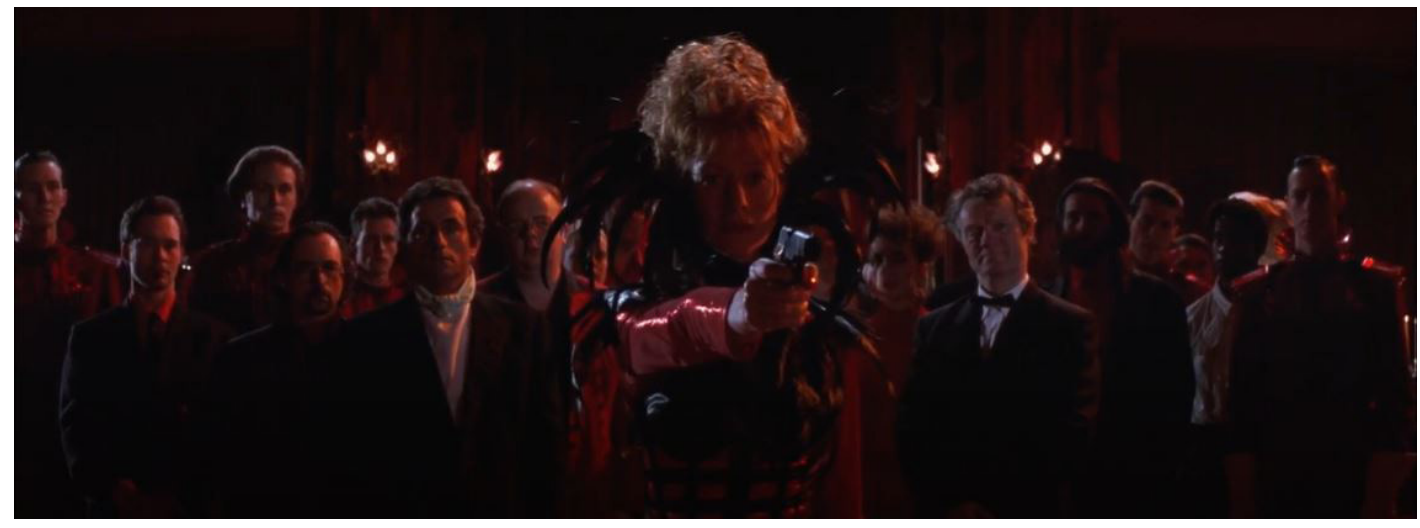

Görsel 14: Georgina, final sahnesinde

Toplumdaki entelektüelleri temsil eden Micheal, tüm bu olanlara protest bir tavır sergilemekten uzak, kendi halinde kitabını okumaktadır. Onun, tüketim çılgınlığına ve abartıya gözü kapalı bu hali Albert'i rahatsız eder. Hiçbir şey yapmadığı halde Albert, onun masasındaki kitapları alıp yere atar, okumasına mâni olur. Georgina ile Micheal'ın tanıştıkları tuvalette Georgina yardım istercesine bakarken Michael, "ne yapabilirim ki” dercesine çaresizce omuz silker. Ancak ilişkilerinin ilerlemesiyle Michael'ın en aktif ve önemli rolünün, Georgina'yı "uyandırmak" ve kitaplarla tanıştırmak olduğu görülür. Kitapların dünyasına giren Georgina, öldürülmüş olan aşığının ağzından çıkan sayfalarla bu kısır döngüdeki çıkış yolunu bulur. Kitabın adı "Fransız Devrimi”dir.

\section{Sonuc}

Peter Greenaway'in birinci sanat ile yedinci sanatı birleştirdiği, yönetmen ve ressam kimliklerini ustaca harmanladığı Aşçı, Hırsız, Karısı ve Aşığı filmi, sunduğu çok katmanlı yapısıyla sinemanın nasıl bir sanat olması gerektiğine dair biçimci bir cevaptır. Filmin özenle inşa edilmiş karakter temsillerinin yanında restoranda asılı duran tabloyla fonuna aldığı 17. yüzyıl Hollanda'sı, film çözümlemesi için gerekli kültürel referansa ışık tutarken renklerse anlatıyı zenginleştirme imkanı sunar. Yoğun renk 
kullanımı, dekorlar ve kostümlerle görsel bir şölen yaratmakla kalmaz mikro ölçekte ortaya koyduğu toplum temsilini Albert'in faşizan karakteri üzerinden yorumlar.

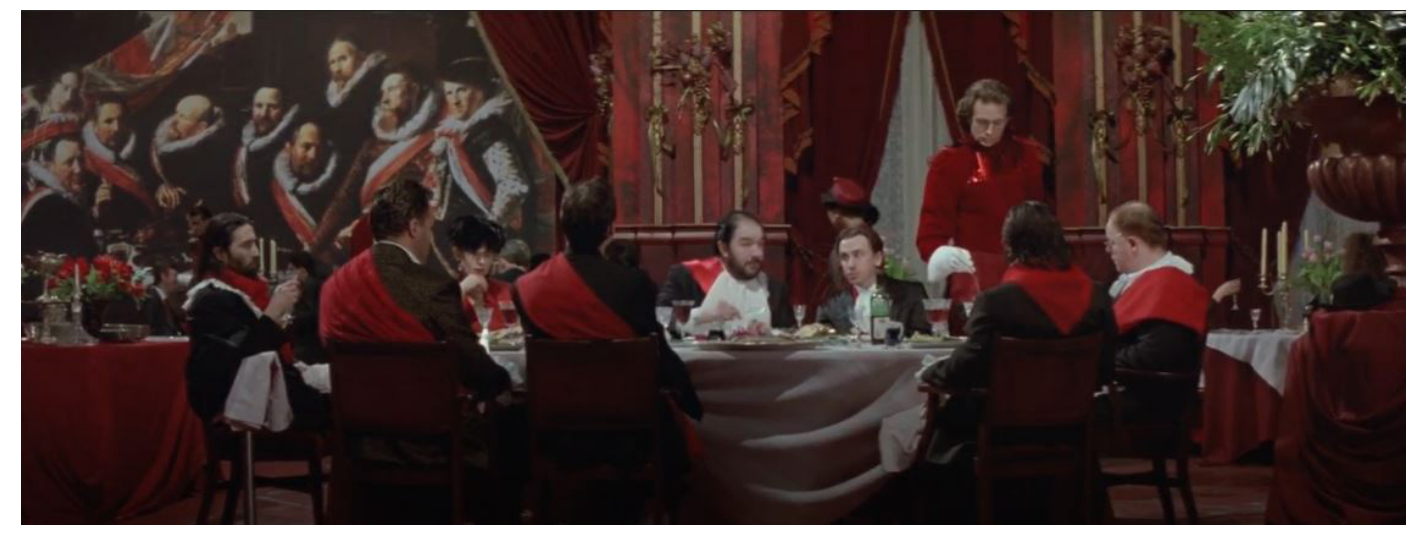

Görsel 15: Albert'in masası ve masasının arkasındaki Frans Hals tablosu

Albert, 17. yüzyılda Hollanda'da olduğu gibi ticarette sağlanan başarıyla kültürel sermayesi olmayan ancak ekonomik sermayeye sahip olan burjuvaların bir örneğini sergiler. Maddi ve sosyal güce sahiptir, himayesinde birçok kişinin yer aldığı yönetici konumundadır. Ancak diğer taraftan kültürel alt yapısının olmayışıyla kaba, ilkel, boş konuşan ve gösteriş düşkünü bir adamdır. Çevresine topladığı adamlarıyla mafyatik tutumlar sergileyen Albert, Frans Hals'in tablosundaki milisler gibidir: Görevlerinin son bulmasına karşın statülerini korumak ve toplum içinde görünür kılmak için masa başında toplanırlar. O dönemlerde törenlerden ve yerine getirilmesi gereken geleneklerden dolayı pek de neşeli geçmeyen bu ziyafetlerde olduğu gibi her akşam pahalı yiyeceklerle kalabalık ziyafetler veren Albert'in masasındakiler de eğlencenin çok uzağındadırlar. Adeta uyuşturulmuşçasına oturup isteksizce yemek yiyerek bu sözde eğlenceye katılırlar. Aralarında istifra edenler ve Albert tarafından darp edilip masadan kovulanlar da vardır. Protestan inancının yansıması olarak Albert, üretimi ve dolayısıyla tüketimi inanç yerine koyar. Filmde yer alan dini referanslı sahnelerin daima mutfakta gerçekleşmesi bu nedenle dikkat çeker. Greenaway'in etkilendiği Barok dönemse filmin tiyatral yapısında, abartılı dekor, kostüm ve oyunculuklarda kendini belli eder. Dönemin coşkusu, ilkesizliği ve mantıktan uzak oluşu filmin tahmin edilemez akışında verilirken restoranda kullanılan siyah, kırmızı ve beyaz renklerin ağırlığı, her mekanda tercih edilen kontrast renkler ve ışık-gölge oyunları yine Barok dönemin ile Rembrandt'ın etkisini gösterir. Rembrandt'ın gerçeği, güzel ve uyumlu olana tercih etmesi gibi yönetmen de anlatısındaki diyalogları güzellik ve estetik olan yerine vücut atıkları üzerine kurmayı tercih eder. Mutfak tezgahlarında ve restorandaki masaların üzerinde görünen meyve sebzeler Hollanda resminde ön plana çıkan natürmortları imler. Masalardaki çeşitli kuşlar ve tavşanlar, av natürmortlarını çağrıştırır. "Mal"a dair olan bu tablolar, sahiplerine getirdiği sahte sahiplik ve prestijle Albert'in kültürel birikimden yoksun gösteriş sevdasını açıklar. Restorana getirdiği varaklı çatal kaşık setleriyle veya sayıca çok fazla olan bardaklarla güç ve prestijini arttırmayı planlamaktadır. Tıpkı o dönemde statü olarak avlanabilme imkanı olmayan bazı burjuvaların, av tabloları sipariş ederek avlanmış gibi yapmaları ve böylece sahte bir "sahipliğe" kavuşmaları gibi.

Peter Greenaway'in auteur bir yönetmen olarak üslubunu etkileyen pek çok öğeyi barındıran Aşçı, Hırsız, Karısı ve Aşığı filmi, sinema ve resim ilişkisinde medyalararasılık bağlamında önemli bir örnektir. Aynı zamanda Greenaway, renk, ışık, kostüm ve dekor gibi mizansene dair öğeleri stilistik bir biçimde kullanarak seçmiş olduğu bu basit konuyu kendine özgü hale getirmeyi başarmış, böylece mizansenin anlatı üzerindeki gücünü ve önemini kanıtlamıştır. 


\section{Kaynakça}

Akdeniz Ay, D. (2017). 17. Yüzyıl Hollanda Resim Sanatında Yiyecek-l̇çecek Öğeleri: Portre, Tür ve Ölüdoğa Sanatından Örneklerle. Journal of Tourism and Gastronomy Studies, 5 (1), 76-95.

Altuntaş, G. Greenaway ve Veritabanı Sineması. Altyazı Sinema Dergisi. https://www.academia.edu/38627606/Greenaway_ve_Veritaban\%C4\%B1_Sinemas\%C4\%B1 adresinden 18.05.2020 tarihinde erişilmiştir.

Berger, J. (2012). Görme Biçimleri. 18. Baskı. Y. Salman (Çev.), İstanbul: Metis Yayınları.

Bonitzer, P. (2011). Kör Alan ve Dekadrajlar. 2. Baskı. İ. Yaşar (Çev.), İstanbul: Metis Yayınları.

Cambridge Dictionary. https://dictionary.cambridge.org/dictionary/english/aspic adresinden 30.06.2020 tarihinde erişilmiştir.

Cambridge Dictionary. https://dictionary.cambridge.org/dictionary/english/boar?q=boars adresinden 30.06.2020 tarihinde erişilmiştir.

Çeler, Z. (2012). 17. Yüzyıl Hollanda Toplumu ve Resim Sanatı Üzerine: Bakış, Üslup ve Yorumlama. Galatasaray Üniversitesi IIletişim Dergisi, 16, 65-84.

Demiray, E. (2014, 29 Ekim). The Cook, The Thief, His Wife \& Her Lover (1989): Perdede Maniyerizm Denemesi. Cine Ritüel. http://www.cinerituel.com/the-cook-the-thief-his-wife-her-lover-1989-perdede-maniyerizm-denemesi/ adresinden 18.05.2020 tarihinde erişilmiştir.

Frans Hals Museum. https://www.franshalsmuseum.nl/en/art/banquet-of-the-officers-of-the-st-george-civic-guard-3/ adresinden 14.06.2020 tarihinde erişilmiştir.

Gombrich, E. H. (2014). Sanatın Öyküsü. Ö. Edruran ve E. Erduran (Çev.), İstanbul: Remzi Kitabevi.

Gras, V. ve Gras, M. (2014). Peter Greenaway. S. Özgül (Çev.), İstanbul: Agora Kitaplığı.

Greenaway Sinemanın Ölümünü İlan Etti. (2007, 11 Ekim). Bianet. https://m.bianet.org/bianet/kultur/102265-greenaway-sinemanin-olumunu-ilan-etti adresinden 18.05.2020 tarihinde erişilmiştir.

IMDb. https://www.imdb.com/name/nm0000425/ adresinden 21.06.2020 tarihinde erişilmiştir.

İslimyeli, B. N. (2014, 27 Kasım). Bir İmge Düşünürü: Peter Greenaway. Belgesel Film. http://www.belgeselfilm.com/ bir-imge-d\%C3\%BC\%C5\%9F\%C3\%BCn\%C3\%BCr\%C3\%BC-peter-greenaway.html adresinden 18.05.2020 tarihinde erişilmiştir.

Kabadayı, L. (2013). Film Eleştirisi: Kuramsal Çerçeve ve Sinemamızdan Örnek Çözümlemeler. İstanbul: Ayrıntı Yayınları.

Kandinsky, W. (2010). Sanatta Ruhsallık Üzerine. İstanbul: Altıkırkbeş Yayın.

Karaalioğlu, O. (2018). 17. Ve 18. Yüzyılda Flaman Resim Sanatında Avcılık Natürmortları. Ídil Dergisi. 7 (48), 909-918.

Karakaya, S. (2015). Sinema-Resim İlişkisi ve Sanat Olarak Sinemanın Resimsel Estetiği. Elektronik Sosyal Bilimler Dergisi. 3 (12), 134-141.

Kasander, K. (Yapımcı) ve Greenaway, P. (Yönetmen). (1989). Aşçı, Hırsız, Karısı ve Aşığı [Sinema Filmi]. Hollanda, İngiltere, Fransa.

Keskinok, A. Siyah - Beyaz ve Renksel Algılamanın Karşılaştırılması. Renkli Televizyon Yapım Tekniği. http://www.kameraarkasi.org/kompozisyon/renk/siyahbeyazverenkkavrami.html adresinden 19.12 .2020 tarihinde erişilmiştir.

Kılıç, L. (2013). Görüntü Estetiği. 5. Baskı. İstanbul: İnkılap Kitabevi. 
Kırık, A. M. (2014). Sinemada Renk Öğesinin Kullanımı: Renk ve Anlatım İlişkisi. 21. Yüzyılda Eğitim ve Toplum Eğitim Bilimleri ve Sosyal Araştırmalar Dergisi, 2 (6), 71-83.

Kilinç, M. ve Köksal, S. (2019). Barok Dönem Resimlerinde Kullanılan Işık Tekniklerinin Günümüz Sinema Filmlerine Yansıması: Kış Uykusu Örneği. ARTS: Artuklu Sanat ve Beşeri Bilimler Dergisi. 1, 19-30.

Kural, N. (2014, 24 Kasım). Yüzüklerin Efendisi ve Harry Potter film değil. Milliyet Sanat. http://www.milliyetsanat.com/ haberler/sinema/-yuzuklerin-efendisi-ve-harry-potter-film-degil-/4722 adresinden 18.05.2020 tarihinde erişilmiştir.

Leppert, R. (2017). Sanatta Anlamın Görüntüsü. 3. Baskı. İ. Türkmen (Çev.), İstanbul: Ayrıntı Yayınları.

Maltaş, M. Ş. (2005). 17. Yüzyıl Hollanda Resim Sanatında Natürmort. (Yayımlanmamış Yüksek Lisans Eser Metni). Mimar Sinan Güzel Sanatlar Üniversitesi Sosyal Bilimler Enstitüsü, İstanbul.

Mazlum, Ö. (2011). Rengin Kültürel Çağrışımları. Dumlupınar Üniversitesi Sosyal Bilimler Dergisi. 31, 125-138.

Peter Greenaway - Biography. (2009, 20 Aralık). The European Graduate School. https://web.archive.org/ web/20091220084927/http://www.egs.edu/faculty/peter-greenaway/biography/ adresinden 18.05 .2020 tarihinde erişilmiştir.

Saskia Boddeke \& Peter Greenaway Projects, https://www.sbpg-projects.com/peter-greenaway adresinden 13.06.2020 tarihinde erişilmiştir.

Sözen, M. (2003). Sinemada Renk. Ankara: Detay Yayıncılık.

Şensöz, A. D. ve Tuncer, A. Ö. (2018, 11 Nisan). Peter Greenaway ile Söyleşi. Altyazı. https://www.altyazi.net/soylesiler/ peter-greenaway-ile-soylesi/ adresinden 18.05.2020 tarihinde erişilmiştir.

Vardan, U. (2009, 13 Nisan). Aykırı Yönetmen Sinema İçin Karamsar. Radikal. http://www.radikal.com.tr/kultur/aykiriyonetmen-sinema-icin-karamsar-931000/ adresinden 18.05.2020 tarihinde erişilmiştir.

Yener Gökşenli, E. (2009). Antonio Muñoz Molina'nın El Invierno En Lisboa Adlı Romanında "Medyalararasılık". I.Ü. Mediterraneo Dergisi, 1 (4), 27-45.

Yücel, M. M. E. (2007). 17. Yüzyıl Hollanda Resminde Sembol Kullanımı. (Yayımlanmamış Yüksek Lisans Tezi). Marmara Üniversitesi Eğitim Bilimleri Enstitüsü, İstanbul.

\section{Extended Abstract}

\section{Introduction}

The symbolic structure of the art of painting and its distance of narrative have attracted the attention of some filmmakers who want to unveil the potential of cinema and have contributed to bring the art of painting to the cinema. One of these filmmakers is Peter Greenaway who brought the elements of the painting to his films, designed his plans like creating a painting. Colour, light and composition which are the elements of movement in the art of painting are noticed that they are at the forefront when this "plan tableau" are examined that he revealed. Based on this, Greenaway's film The Cook, The Thief, His Wife and His Lover, in which the cinema meets the painting, has been examined with an intermedial perspective. The study aims to reveal the effect of painting and the history of painting on cinematic narration and mise-en-scene, and the close relationship between these two art branches. 


\section{Methodology}

The film analysed with mise-en-scene analysing method which is one of the style analyses in the qualitative research methods. In order to provide the requisite cultural background in the purpose of analysing the film, the period in which the work of art was produced is also included with an intermedial approach in the scope of the studying along with the painting of The Banquet of the Officers of the St George Militia Company in 1616. The effect of the aesthetic elements of the painting such as light, colour and composition on the setting of the film was researched. In addition, the role of the social, economic, political and artistic life of the 17th century Netherlands when the painting was produced in the formation of the story of the film was examined.

\section{Conclusions}

Peter Greenaway skilfully displays his identities of director and painter in The Cook, The Thief, His Wife and His Lover. Besides the carefully constructed character representations of the film, 17th century Netherlands, which he took to film's background with the painting hanging in the restaurant, sheds light on the cultural reference required for film analysis. Colours, on the other hand, provide the opportunity to read the film with another method and enrich its meaning. He tells this through Albert's fascist character. Albert is an example of the bourgeoisie who did not have cultural capital but had economic capital with the success in trade in the Netherlands in the 17th century. He has material and social power, he is in the capacity of a manager, many people are under his auspices, but on the other hand he has no cultural infrastructure. He is a rude, primitive, windy and ostentatious man.

Reflections of the Baroque period, which Greenaway was influenced by, are evident in the theatrical structure, exaggerated decor, costumes and acting of the film. The enthusiasm, irregularity and lack of logic of the period are given dynamically in the unpredictable flow of the film. Just as Rembrandt prefers the truth to the beautiful and harmonious, the director prefers to base the dialogues in his narrative on body waste rather than beauty and aesthetics. Fruits and vegetables that appear on kitchen counters and tables in the restaurant mark still-life examples that stand out in Dutch painting. A variety of birds and rabbits evoke hunting still-life paintings. These paintings about "goods" explain the false prestige it brings to its owners, and Albert's passion for show, devoid of cultural accumulation. Just as some bourgeois in the 17th century Netherlands, who were not able to hunt as a status, pretended to be hunters by ordering hunting paintings and thus had a false status.

Peter Greenaway's The Cook, The Thief, His Wife and His Lover is an important example of examining the relationship between cinema and painting in an intermedial context. At the same time, Greenaway has succeeded in making this simple subject unique by using elements of miseen-scène in a stylistic way; thus, he proved the power of mise-en-scène over narrative. 